\title{
OPINI DAN STATUS TINDAK LANJUT REKOMENDASI BADAN PEMERIKSA KEUANGAN PADA PEMERINTAH DAERAH DI KALIMANTAN BARAT, TENGAH, DAN TIMUR
}

\author{
Charles Bohlen Purba \\ Universitas Bhayangkara Jakarta Raya \\ Email: bohlenpurba@yahoo.com
}

\begin{abstract}
The objectives of this study are to analyze and map the progress of the opinion on LKPD as well as to analyze the follow-up status of the BPK recommendation based on the BPK assesment result. The methodology of this research uses bivariate correlation, map of markers radar, and histogram analysis. The opinion on LKPD showed positive and significant progress in West Kalimantan from 2007 to 2008 and in 2009 ; also in Central Kalimantan from 2007 to 2008 as well as in 2010 and 2011 ; and in East Kalimantan from 2007 to 2008 as well as in 2010 and 2011. The map of the opinions on LKPD in West Kalimantan changed from narrow zigzag in 2007-2009 into a stable wide trend in 2011 (13 of 15 entities in the circle of the three maps), whereas in Central and East Kalimantan remained zigzag up to 2011. The status "followed up as recommended" was given by BPK to the three studied regions; West Kalimantan with approximately 3,007 cases which amounted 68.336 billion rupiah, Central Kalimantan with 3,800 cases which was equal to 126.569 billion rupiah, and finally East Kalimantan with 2,350 cases which resulted in 202.01 billion rupiah and USD 1,126,272,000. Conclusion in West Kalimantan, Central Kalimantan, East Kalimantan The Opinion on LKPD have Developed in a Positive.
\end{abstract}

Keywords: Opini of The Local Government Financial Report, Recommendation, Significant, The Status Followed up as Recommended.

\begin{abstract}
Abstrak: Tujuan penelitian ini adalah menganalisis perkembangan opini LKPD, memetakan hasil penilaian opini LKPD, dan menganalisis status tindak lanjut rekomendasi hasil pemeriksaan BPK. Metode penelitian terdiri dari bivariate correlation, pemetaan markers radar, dan analisis histogram. Opini LKPD mengalami perkembangan positif dan signifikan di Kalimantan Barat dari tahun 2007 ke tahun 2008 dan tahun 2009 , di Kalimantan Tengah dari tahun 2007 ke tahun 2008, tahun 2010, dan tahun 2011, dan di Kalimantan Timur dari tahun 2007 ke tahun 2008, tahun 2010, dan tahun 2011. Peta opini LKPD di Kalimantan Barat berubah dari bentuk zig-zag sempit pada tahun 2007 2009 menjadi melebar stabil pada tahun 2011 (13 dari 15 entitas yang berada pada lingkaran ketiga peta), sedangkan peta opini LKPD di Kalimantan Tengah dan Kalimantan Timur tetap zig-zag hingga tahun 2011. Hasil pemeriksaan BPK yang telah ditindaklanjuti dengan status sesuai rekomendasi di Kalimantan Barat sekitar 3.007 kasus dengan nilai Rp 68,336 milyar, di Kalimantan Tengah sekitar 3.800 kasus dengan nilai Rp126,569 milyar , dan di Kalimantan Timur sekitar 2.350 kasus dengan nilai Rp202,01 milyar dan USD1,262.72 ribu. Kesimpulan di Kalimantan Barat, Kalimantan Tengah dan Kalimantan Timur Opini LKPD mengalami perkembangan Positif dan Signifikan.
\end{abstract}

Kata Kunci: opini LKPD, rekomendasi, siginfikan, status tindak lanjut 


\section{PENDAHULUAN}

Rekomendasi Badan Pemeriksa Keuangan (BPK) atas Laporan Keuangan Pemerintah Daerah (LKPD) merupakan upaya untuk memperbaiki pengelolaan dan tanggung jawab keuangan yang dipercayakan kepada setiap entitas Pemerintah Daerah baik di daerah provinsi, kabupaten maupun kota. Sesuai dengan amanat Undang-Undang Dasar Tahun 1945, khususnya Pasal 23 E ayat (2) dan (3), dan Undang-Undang Republik Indonesia Nomor 15 Tahun 2004 Tentang Pemeriksaan Pengelolaan dan Tanggung jawab Keuangan Negara, khususnya pasal 21 ayat (1), maka rekomendasi tersebut harus ditindaklanjuti oleh setiap Entitas Pemerintah Daerah Provinsi/Kabupaten/Kota dan opini yang diberikan harus menjadi acuan untuk perbaikan di tahun-tahun berikutnya.

Menurut BPK (2012a), opini terhadap Laporan Keuangan Pemerintah Daerah (LKPD) harus diberikan sebagai hasil penilaian kerja setiap pemerintah daerah dalam pengelolaan keuangan yang diamanatkan kepadanya, sedangkan tindaklanjut terhadap rekomendasi BPK merupakan bentuk pertanggungjawaban yang melekat ada kegiatan pengelolaan keuangan tersebut. Hal ini penting mengingat tujuan penyusunan Laporan Keuangan Pemerintah Daerah (LKPD) adalah untuk menyajikan informasi mengenai posisi keuangan, realisasi anggaran, arus kas, dan kinerja keuangan yang bermanfaat bagi Entitas Pemerintah Daerah Provinsi/Kabupaten/Kota dalam membuat dan mengevaluasi keputusan mengenai alokasi sumberdaya serta pemanfaatannya dalam upaya memajukan pembangunan dan peningkatan sebenar-benarnya untuk kemakmuran rakyat. Sesuai dengan amanat Undang-Undang Nomor 15 Tahun 2006, Badan Pemeriksa Keuangan (BPK) diberi amanat untuk memberikan rekomendasi evaluatif, penilaian opini, dan pengawasan terhadap tindak lanjut hasil pemeriksaannya.

Terkait dengan penilaian opini atas Laporan Keuangan Pemerintah Daerah (LKPD), Undang-Undang Nomor 15 Tahun 2004 sudah mengatur tentang jenis opini yang bisa diberikan sebagai salah satu bentuk hasil audit atas laporan keuangan tersebut dan ini dinyatakan oleh Suwanda (2013) dalam bukunya tentang Strategi Mendapatkan Opini WTP - Laporan Keuangan PEMDA, yaitu (1) Wajar Tanpa Pengecualian (WTP)/Unqualified Opinion, (2) Wajar dengan pengecualian (WDP)/Qualified Opinion, (3) Tidak wajar/Adverse Opinion, dan 4) Tidak memberikan pendapat/Disclaimer Opinion. Opini LKPD ini menjadi ukuran penting dari akuntabilitas dan transparansi pemerintah daerah dalam pengelolaan keuangan negara di daerah. Perkembangan yang baik terhadap opini LKPD ini dari tahun ke tahun menjadi indikator penting dari kondusifnya pemerintahan daerah yang sedang berlangsung.

Tindak lanjut rekomendasi BPK atas Laporan Keuangan Pemerintah Daerah (LKPD) bisa saja berbeda antar entitas pemerintah daerah yang satu dengan entitas pemerintah daerah lainnya, tergantung kualitas SDM, keterbatasan sarana dan prasarana, luasan wilayah, serta kompleksitas permasalahan yang ada di daerah. Sedangkan menurut Suwanda (2013), kemampuan pengelola keuangan untuk menindaklanjuti rekomendasi yang diberikan oleh auditor sangat dipengaruhi oleh ketersediaan sarana untuk menunjukkan pelaporan yang lebih baik, kualitas dan kapasitas SDM, serta persepsi terhadap pelaporan keuangan yang akuntabel. Sedangkan menurut BPK (2007a), status tindak lanjut terhadap rekomendasi hasil pemeriksaan BPK dapat berupa telah ditindaklanjuti sesuai rekomendasi, dalam proses (belum selesai tindak lanjutnya), belum ditindaklanjuti, dan tidak bisa ditindaklanjuti. 
Entitas pemerintah daerah di Kalimantan dengan wilayahnya yang luas terutama Provinsi Kalimantan Barat, Provinsi Kalimantan Tengah, dan Provinsi Kalimantan Timur, serta kondisi sarana dan prasarananya yang masih terbatas dan banyak lagi keterbatasan lainnya tentu mempunyai capaian tersendiri terkait hasil penilaian opini dan status tindak lanjut atas Laporan Keuangan Pemerintah Daerah (LKPD). Penelitian ini akan mencoba mengkaji lebih dalam apa yang sudah oleh entitas Pemerintah Daerah Provinsi/Kabupaten/Kota yang ada di ketiga provinsi tersebut terkait hasil penilaian opini dan status tindak lanjut atas LKPD-nya.

Tindak lanjut rekomendasi BPK atas Laporan Keuangan Pemerintah Daerah (LKPD) diatur dalam Undang-Undang Dasar Tahun 1945, khususnya Pasal 23 E ayat (2) dan (3) dan Undang-Undang Nomor 15 Tahun 2004 Tentang Pemeriksaan Pengelolaan dan Tanggungjawab Keuangan Negara, khususnya pasal 21 ayat (1). Kedua undang-undang ini memberi arahan tentang perlunya rekomendasi hasil pemeriksaan BPK disampaikan kepada publik termasuk hasil tindak lanjut dari rekomendasi tersebut. Sedangkan BPK (2007a) memberikan arahan tentang status tindak lanjut terhadap rekomendasi hasil pemeriksaan BPK yang dilakukan oleh entitas pemerintah daerah terkait yang terbagi dalam empat jenis status, yaitu telah ditindaklanjuti sesuai rekomendasi, dalam proses (belum selesai tindak lanjutnya), belum ditindaklanjuti, dan tidak bisa ditindaklanjuti. Dalam peneltian ini akan dikembangkan pendekatan histogram untuk mengelompokkan dan menunjukkan status tindak lanjut rekomendasi hasil pemeriksaan BPK atas Laporan Keuangan Pemerintah Daerah (LKPD) pada setiap Entitas Pemerintah Provinsi/Kabupaten/Kota terpilih di ketiga provinsi yang menjadi fokus kajian. Pendekatan ini dapat menunjukkan capaian setiap entitas pemerintah daerah untuk keempat status tindak lanjut tersebut termasuk capaian dalam bentuk nilai uang yang terselamatkan.

Dengan mengacu kepada latar belakang dan kerangka pemikiran penelitian, maka beberapa masalah yang perlu dipecahkan pada kegiatan penelitian opini dan status tindak lanjut hasil pemeriksaan BPK atas Laporan Keuangan Pemerintah Daerah di Kalimantan Barat, Kalimantan Tengah, dan Kalimantan Timur dapat dirumuskan dalam bentuk pertanyaan: (1) Bagimana perkembangan opini Laporan Keuangan Pemerintah Daerah (LKPD) selama periode tahun 2007 - 2011 di Kalimantan Barat, Kalimantan Tengah, dan Kalimantan Timur sebagai wujud akuntabilitas pengelolaan keuangan di daerah?; (2) Bagaimana peta sebaran opini Laporan Keuangan Pemerintah Daerah (LKPD) di Kalimantan Barat, Kalimantan Tengah, dan Kalimantan Timur?; (3) Bagaimana status tindak lanjut rekomendasi hasil pemeriksaan BPK periode tahun 2008 - 2012 di Kalimantan Barat, Kalimantan Tengah, dan Kalimantan Timur, berapa banyak hasil pemeriksaan yang telah dilanjuti sesuai rekomendasi, dalam proses, belum ditindaklanjuti, dan tidak dapat ditindaklanjuti?

Tujuan dari penelitian ini adalah: (1) Menganalisis perkembangan opini Laporan Keuangan Pemerintah Daerah (LKPD) di Kalimantan Barat, Kalimantan Tengah, dan Kalimantan Timur, (2) Memetakan hasil penilaian opini Laporan Keuangan Pemerintah Daerah (LKPD) di Kalimantan Barat, Kalimantan Tengah, dan Kalimantan Timur, (3) Menganalisis status tindak lanjut rekomendasi hasil pemeriksaan BPK periode tahun 2008 - 2012 di Kalimantan Barat, Kalimantan Tengah, dan Kalimantan Timur. 


\section{KAJIAN TEORI}

Landasan Hukum dan Jenis Laporan Keuangan Pemerintah Daerah (LKPD). Menurut Peraturan Menteri Dalam Negeri Nomor 13 Tahun 2006 pasal 1 ayat 6, keuangan yang dikelola oleh Pemerintah Daerah adalah semua hak dan kewajiban daerah dalam rangka penyelenggaraan pemerintahan daerah yang dapat dinilai dengan uang termasuk didalamnya segala bentuk kekayaan yang berhubungan dengan hak dan kewajiban daerah tersebut. Oleh karena itu, pengelolaan semua hak dan kewajiban daerah tersebut harus dilaporkan oleh penyelenggara negara di daerah sebagai bentuk transparansi dan akuntabilitas penggunaannya.

Menurut PP No. 24 tahun 2005 tentang Standar Akuntansi Pemerintahan (PSAP) No. 1 paragraph 9, dinyatakan bahwa Laporan Keuangan Pemerintah Daerah merupakan laporan yang terstruktur mengenai posisi keuangan dan transaksi-transaksi yang dilakukan oleh suatu entitas pelaporan. Sedangkan menurut BPK (2013), penyusunan Laporan Keuangan Pemerintah Daerah (LKPD) merupakan wujud akuntabilitas pengelolaan keuangan negara/daerah. Sesuai dengan Undang Undang Dasar Negara Kesatuan Republik Indonesia Tahun 1945, BPK mempunyai kewajiban dan mandat untuk melakukan pemeriksaan atas laporan keuangan tersebut. Realisasi kewajiban dan mandat tersebut semakin luas seiring dengan pemberian otonomi kepada daerah dalam melakukan pengelolaan keuangan daerah. Pengelolaan keuangan negara yang sebelumnya terpusat di ibu kota negara menjadi tersebar di masing-masing provinsi dan kabupaten/kota.

Tujuan utama laporan keuangan adalah menyajikan informasi mengenai posisi keuangan, realisasi anggaran, arus kas, dan kinerja keuangan suatu entitas pelaporan yang bermanfaat bagi para pengguna dalam membuat dan mengevaluasi keputusan terkait pengelolaan keuangan negara di daerah. Pola penggunaan keuangan tersebut mempengaruhi jenis dan substansi laporan keuangan yang harus disiapkan oleh Pemerintah Provinsi/Kabupaten/Kota. Menurut Suroso (2010), tujuan pelaporan keuangan oleh Pemerintah Daerah adalah untuk menyajikan informasi yang berguna untuk pengambilan keputusan dan untuk menunjukkan akuntabilitas entitas pelaporan atas sumber daya yang dipercayakan kepadanya, dengan: (a) Menyediakan informasi mengenai posisi sumberdaya ekonomi, kewajiban, dan ekuitas dana pemerintah; (b) Menyediakan informasi mengenai perubahan posisi sumberdaya ekonomi, kewajiban, dan ekuitas dana pemerintah; (c) Menyediakan informasi mengenai sumber, alokasi, dan penggunaan sumberdaya ekonomi; (d) Menyediakan informasi mengenai ketaatan realisasi terhadap anggarannya; (e) Menyediakan informasi mengenai cara entitas pelaporan mendanai aktivitasnya dan memenuhi kebutuhan kasnya; (f) Menyediakan informasi mengenai potensi pemerintah untuk membiayai penyelenggaraan kegiatan pemerintahan; (g) Menyediakan informasi yang berguna untuk mengevaluasi kemampuan entitas pelaporan dalam mendanai aktivitasnya.

Jenis laporan keuangan yang harus disajikan oleh pemerintah daerah setidaktidaknya meliputi Laporan Realisasi Anggaran, Neraca, Laporan Arus Kas, dan Catatan Atas Laporan Keuangan. Hal ini juga dinyatakan oleh Undang-Undang Nomor 15 tahun 2004 dan PEMDA Kabupaten Mangelang (2011), yang mengharuskan kepala daerah agar setiap periode tahunan menyiapkan Laporan Realisasi Anggaran (LRA), Laporan Arus Kas (LAK), Neraca dan Catatan Atas Laporan Keuangan (CALK) untuk diperiksa oleh lembaga pemeriksa resmi seperti BPK.

Setiap laporan tersebut mempunyai format tersendiri sesuai dengan tujuan dan jenis data keuangan yang dialporkan. Untuk Laporan Realisasi Anggaran (LRA) misalnya, 
mempunyai 2 (dua) format, yaitu LRA format SAP dan LRA format APBD. Kedua format ini hanya dibedakan pengelompokkan rekening-rekeningnya, contohnya pada format LRA-SAP ada kelompok Belanja Operasi. Sementara format LRA-APBD dibagi kelompok Belanja Tak Langsung dan Belanja Langsung. Sedangkan untuk LAK rekeningrekening dikelompokkan pada kelompok arus kas masuk dan arus kas keluar.

\section{Opini dan Akuntabilitas Laporan Keuangan Pemerintah Daerah (LKPD). Opini} Dalam Penilaian Keuangan Pemerintah Daerah (LKPD). Milal (2013) menyatakan bahwa opini terhadap Laporan Keuangan Pemerintah Daerah (LKPD) merupakan pernyataan professional pemeriksaan oleh BPK atas kewajaran informasi keuangan yang disampaikan dalam Laporan Keuangan Pemerintah Daerah. Hasil penilaian ini bentuk public report penggunaan dana dalam bentuk laporan keuangan yang disusun oleh Pemerintah Daerah (PEMDA) sebagai bentuk pertanggungjawaban kepada masyarakat atas pengelolaan keuangan negara yang diamanatkan kepadanya.

Menurut Mulyadi (2002), ada lima tipe pendapat atas laporan keuangan auditan, yaitu: (1) Pendapat wajar tanpa pengecualian (2) pendapat wajar tanpa pengecualian dengan bahasa penjelasan yang ditambahkan dalam laporan audit baku, (3) pendapat wajar dengan pengecualian, (4) pendapat tidak wajar (5) pernyataan tidak memberikan pendapat. Sedangkan menurut Suwanda (2013), opini yang diberikan terhadap Laporan Keuangan Pemerintah Daerah (LKPD) ada empat jenis, yaitu: 1) Wajar Tanpa Pengecualian (WTP)/Unqualified Opinion, 2) Wajar dengan pengecualian (WDP)/Qualified Opinion, 3) Tidak wajar/Adverse Opinion, dan 4) Tidak memberikan pendapat/Disclaimer Opinion. Pemberian opini tersebut oleh BPK diatur Undang-Undang Nomor 15 Tahun 2004 sebagai salah satu bentuk hasil audit atas laporan keuangan. Secara rinci keempat opini tersebut adalah:

1. Wajar Tanpa Pengecualian (WTP). Opini WTP menyatakan bahwa laporan keuangan disajikan secara wajar dalam semua hal yang material, posisi keuangan, hasil usaha, dan arus kas sesuai dengan prinsip akuntansi yang berlaku umum.

2. Wajar Dengan Pengecualian (WDP). Opini WDP menyatakan bahwa laporan keuangan menyajikan secara wajar dalam semua hal yang material, posisi keuangan, hasil usaha dan arus kas entitas sesuai prinsip akuntansi yang berlaku umum, kecuali untuk dampak hal-hal yang dikecualikan. Kondisi-kondisi yang menyebabkan pemeriksa menyatakan opini WDP adalah sebagai berikut: (a) Tidak adanya bukti kompeten yang cukup atau adanya pembatasan terhadap lingkup audit yang mengakibatkan auditor berkesimpulan bahwa ia tidak dapat menyatakan pendapat wajar tanpa pengecualian dan ia berkesimpulan tidak memberikan pendapat.; (b) Auditor yakin atas dasar auditnya, bahwa laporan keuangan berisi penyimpangan dari prinsip akuntansi berterima umum di Indonesia, yang berdampak material, dan ia berkesimpulan untuk tidak menyatakan pendapat tidak wajar.

3. Tidak Wajar (TW). Auditor menyatakan bahwa laporan keuangan tidak menyajikan secara wajar posisi keuangan, hasil usaha, dan arus kas entitas tertentu sesuai dengan prinsip akuntansi berterima umum.

4. Tidak Memberikan Pendapat (TMP). Kondisi-kondisi yang menyebabkan pemeriksa menyatakan opini TMP adalah sebagai berikut. Pemeriksa tidak melaksanakan audit yang berlingkup memadai untuk memungkinkan auditor memberikan pendapat atas laporan keuangan dan Jika pemeriksa dalam kondisi tidak independen dalam hubungannya dengan klien. 
Setiap lembaga pemerintah termasuk entitas Pemerintah Daerah Provinsi/Kabupaten/Kota mempunyai harapan untuk mendapatkan opini Wajar Tanpa Pengecualian (WTP) atas laporan keuangan yang dibuatnya. Opini WTP adalah instrument dalam pengambilan keputusan yang tepat sebagai bentuk akuntabilitasnya laporan keuangannya. Untuk mencapai hal ini, maka Pemerintah Daerah perlu melakukan berbagai upaya mulai pemilihan jenis kegiatan/program yang dibiayai, pengawasan realisasi program, perbaikan sistem dalam pengelolaan dan pelaporan keuangan, serta pembinaan sumberdaya pengelola dan penyusun laporan keuangan (Rahmanti dan Prastiwi, 2011).

Jenis opini yang didapat oleh setiap entitas Pemerintah Daerah Provinsi/Kabupaten/Kota sangat tergantung pada kualitas laporan keuangannya yang diserahkannya. Disinilah peran dari semua pihak yang terlibat dalam penyusunan Laporan Keuangan Pemerintah Daerah (LKPD), termasuk peran auditor daerah yang melaksanakan tugas Pengawasan Intern yakni seluruh proses kegiatan audit, review, evaluasi, pemantauan, dan kegiatan pengawasan lain diharapkan mampu untuk meningkatkan kualitas LKPD tersebut.

Akuntabilitas Laporan Keuangan Pemerintah Daerah (LKPD). Sebagai Aparat Pengawas Intern Pemerintah (APIP), BPKP membantu mewujudkan akuntabilitas dalam pelaporan keuangan negara dan daerah. Kegiatan yang dilakukan BPKP untuk mendukung terwujudnya akuntabilitas pelaporan keuangan meliputi antara lain (Suwanda, 2013 dan Milal, 2013): (1) Kegiatan pendampingan penyusunan laporan keuangan K/L/pemda, (2) Review laporan keuangan K/L/pemda sebelum diaudit oleh BPK, (3) Menindaklanjuti hasil temuan BPK, (4) Pendampingan perbaikan sistem pelaporan, (5) Implementasi Sistem Informasi Manajemen Daerah (SIMDA), (6) Sosialisasi, pembentukan satgas, dan workshop SPIP, dan (7) Peningkatan kapasitas SDM pengelolaan keuangan daerah dan APIP. Secara umum, beberapa faktor yang menyebabkan laporan keuangan K/L dan pemda tersebut belum memperoleh opini WTP adalah karena penyajian yang belum sepenuhnya sesuai Standar Akuntansi Pemerintahan (SAP), lemahnya sistem pengendalian intern, belum tertatanya barang milik negara/daerah dengan tertib, pengadaan barang yang belum mengikuti ketentuan yang berlaku, dan kurang memadainya kapasitas SDM pengelola keuangan.

Menurut BPK (2007b), akuntabilitas Laporan Keuangan Pemerintah Daerah (LKPD) ditunjukkan oleh hasil penilaian opini terhadap LKPD tersebut. Opini WTP menjadi tujuan dalam pengelolaan keuangan publik sebagai tuntutan reformasi birokrasi. Opini WTP menjadi salah satu indikator yang mencerminkan keberhasilan reformasi birokrasi pada kementerian/lembaga bersangkutan. Akuntabilitas dan transparansi menjadi budaya tanggung jawab penggunaan anggaran negara perlu terus dikembangkan sebagai bentuk pertanggungjawaban publik kepada masyarakat luas. Laporan keuangan yang dibuat oleh lembaga pemerintah di pusat dan daerah merupakan gambaran akuntabilitas penggunaan dana yang berasal dari anggaran negara, dengan semakin baik dan bertanggung jawab dalam penggunaannya, maka BPK akan memberikan opini Wajar Tanpa Pengecualian (WTP) terhadap laporan keuangan yang diperiksa.

Tindak Lanjut Rekomendasi BPK Atas Laporan Keuangan Pemerintah Daerah (LKPD). Menurut Peraturan Pemerintah No. 24 Tahun 2005 tentang Standar Akuntansi Pemerintahan, kerangka konseptual akuntansi pemerintahan paragraph 21 sampai 22 dinyatakan bahwa Laporan keuangan disusun untuk menyediakan informasi yang relevan 
mengenai posisi keuangan dan seluruh transaksi yang dilakukan oleh suatu Entitas Pemerintah Provinsi/Kabupaten/Kota. Setiap Entitas Pemerintah Provinsi/Kabupaten/Kota ini mempunyai kewajiban untuk melaporkan upaya-upaya yang telah dicapai dalam pelaksanaan kegiatan secara sistematis dan terstruktur pada suatu periode pelaporan untuk diperiksa oleh lembaga berwewenang yang dalam hal ini adalah Badan Pemeriksa Keuangan (BPK).

Hasil pemeriksaan BPK ini nantinya selain dalam bentuk opini juga dalam bentuk rekomendasi-rekomendasi yang perlu ditindaklanjuti. Secara umum, rekomendasi BPK atas Laporan Keuangan Pemerintah Daerah (LKPD) setelah mempertimbangkan:

1. Akuntabilitas, Rekomendasi terkait akuntabilitas ini diberikan bila dirasa terhadap kekurangan dalam hal pertanggungjawaban pengelolaan sumberdaya serta pelaksanaan kebijakan yang dipercayakan kepada Pemerintah Provinsi/Kabupaten/Kota dalam rangka pencapaian tujuan yang telah ditetapkan secara periodik.

2. Manajerial. Rekomendasi berkaitan dengan manajerial dalam dalam pelaporan tersebut ada keraguan dan kurang dalam hal-hal yang terkait dengan perencanaan dan pengelolaan keuangan pemerintahan serta pengendalian yang efektif atas seluruh aset, hutang, dan ekuitas dana yang dikelola oleh pemerintah daerah.

3. Transparansi. Rekomendasi diberikan bila informasi keuangan yang diberikan dirasakan kurang transparan dan ada yang informasinya tidak jelas untuk diketahui masyarakat dalam rangka mewujudkan penyelenggaraan pemerintahan yang baik.

4. Keseimbangan antar generasi (intergrational equity). Rekomendasi terkait hal ini diberikan untuk membantu para pengelola keuangan di daerah mengenai kecukupan penerimaan pemerintah pada periode pelaporan untuk membiayai seluruh pengeluaran yang dialokasikan dan apakah generasi yang akan datang diasumsikan akan ikut menanggung beban pengeluaran tersebut.

Memenuhi Undang Undang Nomor 15 Tahun 2004 Pasal 20 bahwa, BPK memantau pelaksanaan tindak lanjut rekomendasi hasil pemeriksaan dan memberitahukan hasil pemantauan tindak lanjut kepada lembaga perwakilan dalam hasil pemeriksaan semesteran, maka dalam IHPS dimuat data pemantauan pelaksanaan tindak lanjut hasil pemeriksaan atas pengelolaan dan tanggung jawab keuangan negara yang dilakukan oleh setiap kepala daerah di setiap Entitas Pemerintah Provinsi/Kabupaten/Kota.

Tindak lanjut terhadap rekomendasi BPK merupakan amant dari Undang-Undang Nomor 33 Tahun 2004 (pasal 103) terkait transparansi dan akuntabilitas pengelolaan keuangan oleh penyelenggara negara termasuk di daerah. Dalam Undang Nomor 33 Tahun 2004 ini dinyatakan bahwa informasi yang termuat dalam sistem informasi keuangan daerah sebagaimana yang dimaksudkan dalam pasal 101 merupakan data terbuka yang dapat diketahui, diakses dan diperoleh masyarakat. Maka dari uraian diatas dapat disimpulkan bahwa transparansi dan akuntabilitas keuangan daerah adalah pertanggungjawaban pemerintah daerah yang berkenaan dengan pengelolaan keuangan daerah kepada masyarakat secara terbuka dan jujur melalui media berupa penyajian laporan keuangan yang dapat diakses oleh berbagai pihak yang berkepentingan dengan anggapan bahwa masyarakat berhak mengetahui informasi tersebut. Oleh karena setiap temuan hasil pemeriksaan BPK harus ditindaklanjuti untuk transparansi dan akuntabilitas pelaporan di masa yang akan datang.

Menurut BPK (2009), temuan-temuan pemeriksaan yang oleh BPK dinyatakan selesai ditindaklanjuti adalah temuan-temuan pemeriksaan yang direkomendasikan telah ditindaklanjuti secara nyata dan tuntas oleh Entitas Pemerintah Provinsi/Kabupaten/Kota 
yang diperiksa sehingga diharapkan dapat memperbaiki pengelolaan dan tanggung jawab keuangan pada entitas yang bersangkutan. Misalnya, suatu temuan pemeriksaan memuat rekomendasi mengenai penagihan atas kelebihan bayar atau denda yang belum dipungut dan hasil penagihan/pemungutan harus disetor ke Kas Negara/Daerah, maka temuan pemeriksaan tersebut dinyatakan selesai jika Entitas Pemerintah Provinsi/Kabupaten/Kota yang bersangkutan telah menyetor seluruh penagihan/pemungutannya ke kas Negara/Daerah dan BPK telah menerima bukti setor tersebut. Sebaliknya, apabila bukti tindak lanjut tidak diterima dan/atau baru diterima sebagian, maka temuan pemeriksaan yang bersangkutan dinyatakan belum selesai ditindaklanjuti.

Kerangka Pemikiran. Undang Undang Nomor 15 Tahun 2004 menyatakan bahwa BPK diberi kewenangan untuk memberi penilaian terhadap Laporan Keuangan Pemerintah Daerah (LKPD), memberi rekomendasi yang diperlukan berdasarkan hasil pemeriksaannya terhadap LKPD tersebut, serta memantau proses tindak lanjut atas rekomendasi tersebut, dimana hasil kerja BPK ini kepada masyarakat melalui lembaga perwakilan yang resmi. Dewan Perwakilan Daerah (DPD) yang anggotanya berasal dari semua daerah di tanah air, akan mendapat laporan langsung terkait hasil pemeriksaan Laporan Keuangan Pemerintah Daerah (LKPD) tersebut dari BPK pada persidanganpersidangan resmi DPD dengan BPK. Namun demikian, laporan tersebut umumnya bersifat global, tidak mendalam, serta tidak banyak diketahui oleh masyarakat umum. Hal inilah yang menjadi pemikiran dilakukan penelitian ini, apalagi menurut perintah undangundang harus disampaikan secara luas, mendalam serta transparan kepada masyarakat.

Penelitian akan membantu menganalisis perkembangan opini LKPD tersebut, memetakan capaiannnya dari tahun ke tahun, serta menganalisis status tindak lanjut dari setiap LKPD yang diserahkan oleh setiap Pemerintah Daerah Provinsi/Kabupaten/Kota terpilih di ketiga provinsi yang menjadi lokasi kajian. Menurut Suwanda (2013) dan Suroso (2010), Laporan Keuangan Pemerintah Daerah (LKPD) merupakan bentuk pertanggungjawaban Pemerintah Daerah dalam mengelola anggaran masyarakat diamanatkan oleh negara kepadanya melalui Undang-Undang. Mengacu kepada hal ini, maka sangat wajar bila informasi mendalam terkait hasil penilaian opini dan tindak lanjut rekomendasi BPK atas LKPD tersebut dapat diberikan kepada masyarakat luas melalui penelitian ini. Secara skematis, kerangka pemikiran penelitian disajikan pada Gambar 1.

Hasil penilaian opini terhadap Laporan Keuangan Pemerintah Daerah (LKPD) tentunya diharapkan positif, artinya ada peningkatan dari tahun ke tahun dan itu terlihat nyata/signifikan dari respon BPK terhadap LKPD serta dapat dipertanggungjawabkan akuntabilitas kepada publik. Hal ini ingin dicapai melalui penelitian ini dengan mengembangkan analisis bivariate correlation. Dalam analisis ini, hasil penilaian opini LKPD oleh BPK akan dikaji keterkaitannya dari tahun ke tahun, dan bila keterkaitan/korelasi positif signifikan berarti ada perkembangan atau perbaikan opini secara nyata dari LKPD yang diserahkan setiap entitas pemerintah daerah dari tahun ke tahun dan ini sangat baik untuk mengangkat citra daerah.

Pada Gambar 1. hasil penilaian tersebut kemudian dipetakan untuk mengetahui posisi suatu entitas pemerintah daerah dibandingkan yang lainnya terkait opini LKPD-nya, bentuk sebaran serta perkembangan opini dari tahun ke tahun. Untuk maksud ini, dikembangkan metode pemetaan markers radar yang mana bentuk sebaran serta perkembangan opini LKPD akan diilustrasikan dalam bentuk jangkauan radar pada lingkaran peta. 


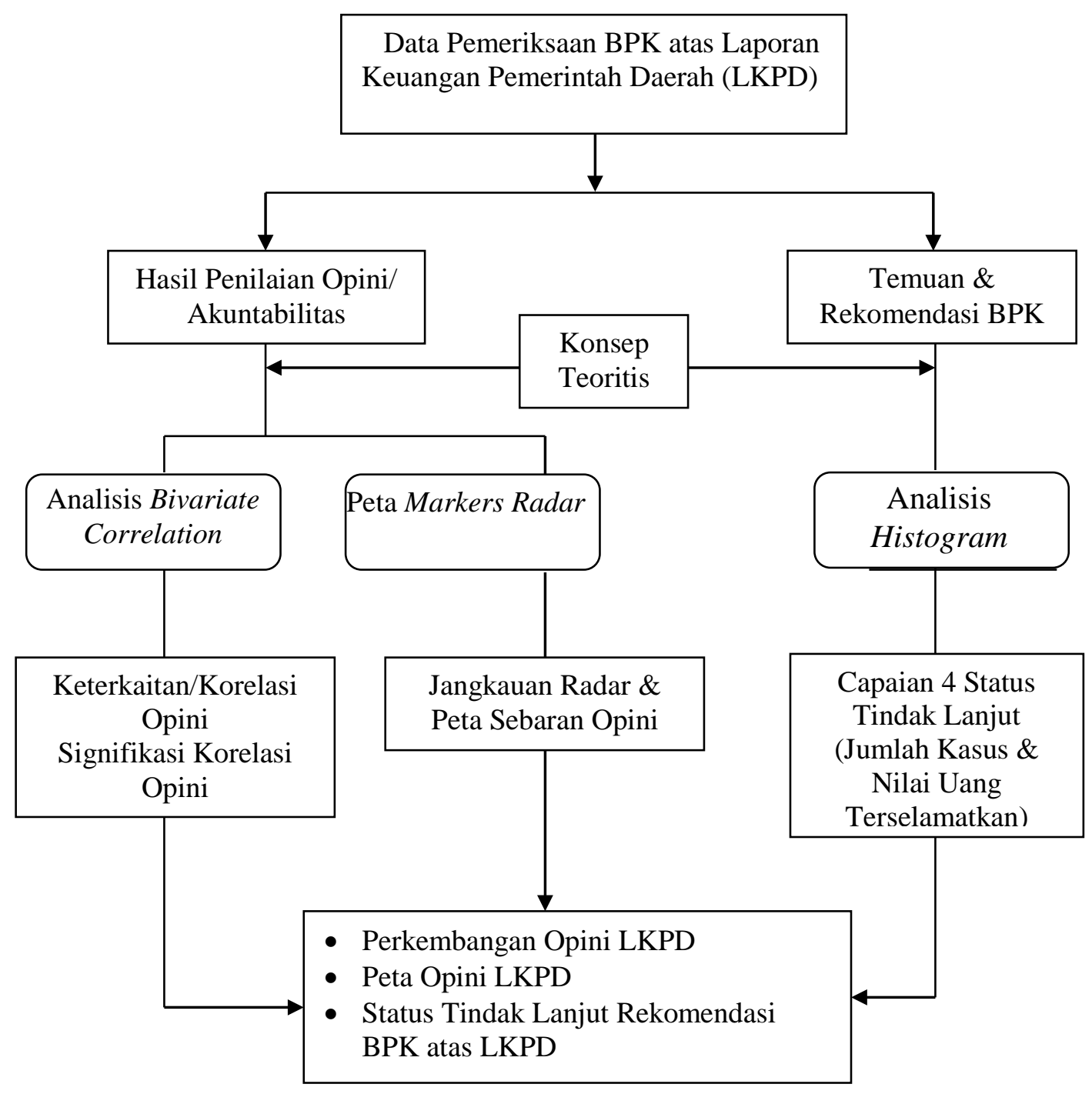

Gambar 1. Kerangka pemikiran penelitian

\section{METODE}

Jenis Data dan Metode Pengumpulan Data. Data yang dikumpulkan terdiri dari data primer dan data sekunder terkait hasil pemeriksaan BPK atas Laporan Keuangan Pemerintah Daerah (LKPD) di setiap Entitas Pemerintah Provinsi/Kabupaten/Kota terpilih di Kalimantan Barat, Kalimantan Tengah, dan Kalimantan Timur.Data tersebut mencakup: (a) Laporan Keuangan Pemerintah Daerah (LKPD) periode 2007 - 2011; (b) Data penilaian akuntabilitas pengelolaan keuangan pemerintah daerah periode tahun 2007 2011; (c) Data temuan dan rekomendasi Hasil Pemeriksaan BPK; (d) Data jumlah kasus yang ditindaklanjuti dan yang belum ditindaklanjuti sesuai rekomendasi BPK periode tahun 2008 - 2012; (e) Data nilai uang (baik dalam mata uang rupiah maupun mata uang asing) yang melekat yang direkomendasikan oleh BPK periode tahun 2008 - 2012; (f) Data jumlah kerugian negara yang berhasil diselamatkan periode tahun 2008 - 2012; (g) Data jumlah kerugian negara telah disetor ke Kas Negara periode tahun 2008 - 2012 
Penelitian ini dilakukan pada bulan Pebruari 2014 sampaii dengan bulan Mei 2014. Tempat penelitian ini adalah Kalimantan Barat, Kalimantan Tengah, dan Kalimantan Timur. Sedangkan lokasi pengambilan data di ketiga propinsi tersebut adalah 15 Entitas Pemerintah Provinsi/Kabupaten/Kota terpilih di Kalimantan Barat, Kalimantan Tengah, dan Kalimantan Timur seperti disajikan pada Tabel 1.

Tabel 1. Lokasi pengambilan data

\begin{tabular}{clll}
\hline \multirow{2}{*}{ No. } & \multicolumn{3}{c}{ Entitas Pemerintah Provinsi/Kabupaten/Kota } \\
\cline { 2 - 4 } & \multicolumn{1}{c}{ Kalimantan Barat } & \multicolumn{1}{c}{ Kalimantan Tengah } & \multicolumn{1}{c}{ Kalimantan Timur } \\
\hline 1. & Prov. Kalbar & Prov. Kalteng & Prov. Kaltim \\
2. & Kab. Bengkayang & Kab. Barito Selatan & Kab. Berau \\
3. & Kab. Kapuas Hulu & Kab. Barito Timur & Kab. Bulungan \\
4. & Kab. Kayong Utara & Kab. Barito Utara & Kab. Kubar \\
5. & Kab. Ketapang & Kab. Gunung Mas & Kab. Kukar \\
6. & Kab. Kubu Raya & Kab. Kapuas & Kab. Kutim \\
7. & Kab. Landak & Kab. Katingan & Kab. Malinau \\
8. & Kab. Melawi & Kab. Kobar & Kab. Nunukan \\
9. & Kab. Pontianak & Kab. Kotim & Kab. Paser \\
10. & Kab. Sambas & Kab. Lamandau & Kab. PPU \\
11. & Kab. Sanggau & Kab. Murung Raya & Kab. Tana Tidung \\
12. & Kab. Sekadau & Kab. Pulang Pisau & Kota Balikpapan \\
13. & Kab. Sintang & Kab. Seruyan & Kota Bontang \\
14. & Kota Pontianak & Kab. Sukamara & Kota Samarinda \\
15. & Kota Singkawang & Kota Palangka Raya & Kota Tarakan \\
\hline
\end{tabular}

Analisis Data. Analisis yang digunakan dalam penelitian ini terdiri dari analisis bivariate correlation, pemetaan markers radar, dan analisis histogram. Analisis bivariate correlation digunakan untuk mengetahui perkembangan opini LKPD dengan cara menganalisis keterkaitan dari tahun ke tahun. Menurut Sarwono (2006), metode bivariate correlation membantu menganalisis keterkaitan/korelasi/hubungan suatu variabel terhadap variabel lainnya yang terlibat suatu interaksi berantai. Korelasi tersebut akan mencerminkan tingkat hubungan/keterkaitan suatu variabel terhadap variabel lainnya dalam berinteraksi. Berdasarkan nilai koefisien korelasi yang didapat, maka keterkaitan/korelasi/hubungan suatu variabel terhadap variabel lainnya dapat dikelompokkan menjadi empat (Sarwono, 2006), yaitu: keterkaitan (correlation) lemah: $0-0,25$, keterkaitan (correlation) cukup: $>0,25-0,5$, keterkaitan (correlation) kuat: $>0,5$ $-0,75$, keterkaitan (correlation) sangat kuat: $>0,75-1$. Nilai tersebut bisa positif dan negatif, dimana bila positif berarti ada keterkaitan atau perkembangan positif terhadap opini LKPD dari tahun ke tahun, sedangkan bila negatif berarti ada keterkaitan atau perkembangan negatif terhadap opini LKPD tersebut. Keterkaitan atau perkembangan opini LKPD bisa dipercaya bila mempunyai signifikansi (sig) $<0,05$.

Metode markers radar digunakan untuk memetakan hasil penilaian opini LKPD selama periode tahun 2007-2011 dari Entitas Pemerintah Provinsi/Kabupaten/Kota terpilih pada setiap provinsi. Jangkuan radar pada peta tersebut dibagi menjadi 4, yaitu lingkaran pertama yang berarti opini Tidak Memberikan Pendapat (TMP), lingkaran kedua yang berarti opini Tidak Wajar (TW), lingkaran ketiga yang berarti opini Wajar Dengan Pengecualian (WDP), dan lingkaran keempat yang berarti opini Wajar Tanpa 
Pengecualian (WTP) (Mustaruddin, et. al, 2011). Mengacu hal ini, maka semakin baik opini LKPD bila jangkauan radar semakin lebar, sebaliknya bila jangkauan radar semakin sempit. Peta opini LKPD yang zig-zag menunjukkan capaian opini LKPD pada tahun tertentu beragam, sedangkan peta opini LKPD yang stabil pada suatu lingkaran peta menunjukkan capaian opini LKPD pada tahun tertentu relatif sama untuk entitas PEMDA yang dikaji pada setiap provinsi.

Analisis histogram digunakan untuk mengetahui status tindak lanjut rekomendasi hasil pemeriksaan BPK atas Laporan Keuangan Pemerintah Daerah (LKPD) pada setiap Entitas Pemerintah Provinsi/Kabupaten/Kota terpilih di ketiga provinsi. Mengacu kepada BPK (2007a), status tindak lanjut rekomendasi BPK tersebut terdiri dari telah ditindaklanjuti sesuai rekomendasi, dalam proses (belum selesai tindak lanjutnya), belum ditindaklanjuti, dan tidak bisa ditindaklanjuti. Terkait dengan ini, maka setiap Entitas Pemerintah Provinsi/Kabupaten/Kota terpilih di ketiga provinsi akan dianalisis tindak lanjut rekomendasi BPK atas LKPD-nya menggunakan empat status tersebut, yang kemudian dibuat hisgtogramnya.

\section{HASIL DAN PEMBAHASAN}

Perkembangan Opini LKPD di Provinsi Kalimantan Barat. Opini terhadap Laporan Keuangan Pemerintah Daerah (LKPD) merupakan bentuk penilaian substantif dari laporan keuangan yang disampaikan setiap tahunnya oleh penyelenggara negara baik di pusat maupun daerah. Baik tidaknya hasil penilaian opini menjadi ukuran akuntabilitas dari penggunaan uang negara yang dipercayakan kepada penyelenggara negara tersebut. Konsistensi akuntabilitas pelaporan dari penyelenggara negara dapat dilihat dari perkembangan dan tingkat keeratan hasil penilain opini laporan keuangan tersebut dari tahun yang satu dengan tahun lainnya. Tabel 1 menyajikan hasil analisis perkembangan opini LKPD di Provinsi Kalimantan Barat.

Berdasarkan Tabel 2, opini LKPD tahun 2007 mempunyai keterkaitan yang positif kuat dengan opini LKPD tahun 2008 dan opini LKPD tahun 2009. Hal ini ditunjukkan oleh nilai PC (pearson correlation) keterkaitan opini LKPD dari tahun 2007 ke tahun 2008 dan tahun 2009 yang positif berada dalam range $<0,5-0,75$, yaitu masing-masing mencapai 0,712 dan 0,549 . Nilai PC tersebut dapat dipercaya karena mempunyai nilai sig $<0,05$, yaitu masing-masing 0,03 dan 0,034.

Hasil analisis pada Tabel 2 menunjukkan bahwa akuntabilitas laporan keuangan yang diberikan oleh 15 entitas pemerintah provinsi/kabupaten/kota di Kalimantan Barat konsisten meningkat nyata dari tahun 2007 ke tahun 2008 dan tahun 2009. Pada tahun 2007, Secara keseluruhan, akuntabilitas LKPD dari penyelenggara negara di Kalimantan Barat ini cenderung meningkat yang ditunjukkan oleh sifat nilai PC yang positif untuk semua bentuk korelasi (Tabel 1), meskipun tidak semuanya nyata/signifikan. Tabel 3 menyajikan hasil penilaian opini LKPD di wilayah Provinsi Kalimantan Timur Tahun 2007 - 2011.

Keterkaitan kuat dan nyata juga terjadi untuk opini LKPD tahun 2008 dengan tahun 2010 (nilai PC 0,563 dengan sig <0,05 yaitu 0,09) dan untuk opini LKPD tahun 2010 dengan opini LKPD tahun 2011 (nilai PC 0,537 dengan sig 0,039). Hal ini relevan dengan hasil penilaian opini LKPD pada Tabel 2, dimana entitas pemerintah daerah di Kalimantan Tengah yang mendapat opini Wajar Dengan Pengecualian (WDP) dan Wajar Tanap Pengecualisan (WTP) ada 6 entitas pada tahun 2008, meningkat menjadi 13 entitas pada 
tahun 2010 dan 14 entitas pada tahun 2011. Hanya Kabupaten Melawai yang mendapat penilaian kurang baik (Tidak Wajar/TW) pada tahun 2011.

Tabel 2. Perkembangan opini LKPD di Provinsi Kalimantan Barat

\begin{tabular}{|c|c|c|c|c|c|c|}
\hline & & X1 (2007) & X2 (2008) & X3 (2009) & X4 (2010) & X5 (2011) \\
\hline \multirow[t]{3}{*}{$\overline{X 1}(2007)$} & \multirow{3}{*}{$\begin{array}{l}\text { Pearson Correlation } \\
\text { Sig. (2-tailed) } \\
\mathrm{N}\end{array}$} & 1 &, $712^{* *}$ & ,549* & ,460 & \multirow{3}{*}{$\begin{array}{r}\text {,330 } \\
\text { 230 }\end{array}$} \\
\hline & & & ,003 & ,034 & ,084 & \\
\hline & & 15 & 15 & 15 & 15 & \\
\hline \multirow[t]{3}{*}{ X2 (2008) } & \multirow{3}{*}{$\begin{array}{l}\text { Pearson Correlation } \\
\text { Sig. (2-tailed) } \\
\text { N }\end{array}$} &, $712^{* *}$ & 1 & ,417 &, $563^{*}$ & \multirow{3}{*}{$\begin{array}{r}, 000 \\
1,000 \\
15\end{array}$} \\
\hline & & ,003 & & 122 & ,029 & \\
\hline & & 15 & 15 & 15 & 15 & \\
\hline \multirow[t]{3}{*}{ X3 (2009) } & Pearson Correlation &, $549^{*}$ & ,417 & \multirow[t]{2}{*}{1} & 094 & ,219 \\
\hline & Sig. (2-tailed) & ,034 & 122 & & 738 & 432 \\
\hline & $\mathrm{N}$ & 15 & 15 & 15 & 15 & 15 \\
\hline \multirow[t]{3}{*}{ X4 (2010) } & Pearson Correlation & 460 &, $563^{*}$ & ,094 & \multirow[t]{2}{*}{1} &, $537^{*}$ \\
\hline & Sig. (2-tailed) & ,084 & 029 & 738 & & 039 \\
\hline & $\mathrm{N}$ & 15 & 15 & 15 & 15 & 15 \\
\hline \multirow[t]{3}{*}{ X5 (2011) } & Pearson Correlation & ,330 &, 000 & ,219 &, $537^{*}$ & \\
\hline & Sig. (2-tailed) & ,230 & 1,000 & ,432 & ,039 & \\
\hline & $\mathrm{N}$ & 15 & 15 & 15 & 15 & 15 \\
\hline \multicolumn{7}{|c|}{$\begin{array}{l}* * \text {. Correlation is significant at the } 0.01 \text { level (2-tailed). } \\
\text { *. Correlation is significant at the } 0.05 \text { level ( } 2 \text {-tailed). }\end{array}$} \\
\hline
\end{tabular}

Tabel 3. Opini LKPD di Wilayah Provinsi Kalimantan Barat Tahun 2007 - 2011

\begin{tabular}{rlccccc}
\hline \multirow{2}{*}{ No } & \multicolumn{1}{c}{ Entitas } & \multicolumn{5}{c}{ Opini LKPD } \\
\cline { 3 - 7 } & \multicolumn{1}{c}{ Pemerintah Daerah } & 2007 & 2008 & 2009 & 2010 & 2011 \\
\hline 1 & Prov. Kalimantan Barat & TMP & TMP & WDP & WDP & WDP \\
2 & Kab. Bengkayang & TMP & TW & TMP & WDP & WDP \\
3 & Kab. Kapuas Hulu & TW & TW & TMP & WDP & WDP \\
4 & Kab. Kayong Utara & - & TMP & TMP & WDP & WDP \\
5 & Kab. Ketapang & WDP & WDP & WDP & WDP & WDP \\
6 & Kab. Kubu Raya & - & - & TW & TW & WDP \\
7 & Kab. Landak & TW & TW & TW & WDP & WDP \\
8 & Kab. Melawai & TMP & TMP & TW & TW & TW \\
9 & Kab. Pontianak & WDP & WDP & WDP & WDP & WDP \\
10 & Kab. Sambas & TMP & WDP & WDP & WDP & WDP \\
11 & Kab. Sanggau & WDP & WDP & WDP & WDP & WDP \\
12 & Kab. Sekadau & TMP & TMP & TMP & WDP & WDP \\
13 & Kab. Sintang & WDP & WDP & WDP & WDP & WDP \\
14 & Kota Pontianak & WDP & TMP & WDP & WDP & WTP \\
15 & Kota Singkawang & WDP & WDP & TW & WDP & WDP \\
\hline
\end{tabular}

Sumber: BPK (2012b) 
Menurut PEMDA Provinsi Kalimantan Barat (2013), opini tidak wajar atas LKPD Kabupaten Melawai ini lebih disebabkan oleh kualitas SDM pengelola laporan keuangan tersebut yang masih rendah, dan belum ada pembinaan khusus terhadap mereka. Lokasi Kabupaten Melawai yang jauh dari ibukota propinsi dan berbatasan langsung dengan Provinsi Kalimantan Tengah menyebabkan wilayahnya cukup sulit diakses termasuk untuk kepentingan pengembangan dan pembinaan penyelenggara negara di Kabupaten tersebut.

Berdasarkan Tabel 3, pada periode tahun 2007 - 2011 baru 1 (satu) entitas pemerintah daerah di Provinsi Kalimantan Barat yang memperoleh opini Wajar Tanpa Pengecualian (WTP) atas LKPD Tahun 2011, yaitu Pemerinah Kota Pontianak. Opini WTP dalam penilaian LKPD ini merupakan hasil penilaian terbaik dan dapat dikatakan sempurna karena sangat akuntabel, transparan, dan terbebas dari berbagai kejanggalan. Dengan berbagai keterbatasan yang ada terkait kualitas SDM, keterbatasan sarana dan prasarana, serta kompleksitas permasalahan yang ada di daerah, maka hasil penilaian dengan opini Wajar Dengan Pengecualian (WDP) atas LKPD Pemerintah Provinsi/Kabupaten/Kota sudah termasuk baik untuk kondisi saat ini. Salah satu indikasi dari Provinsi/Kabupaten/Kota yang maju dan berkembang di masa datang adalah transparan dalam pengelolaan keuangan dan ada perbaikan yang terus menerus terhadap kekurangannya (Simanjuntak, 2005).

Perkembangan Opini LKPD di Provinsi Kalimantan Tengah. Perkembangan opini atas Laporan Keuangan Pemerintah Daerah (LKPD) di Provinsi Kalimantan Tengah disajikan pada Tabel 4. Mengacu kepada Tabel 3 tersebut, kerterkaitan antar opini LKPD selama periode tahun 2007 - 2011, semuanya bersifat positif yang ditunjukkan oleh nilai PC $>0,000$. Hal ini menunjukkan bahwa perkembangan opini yang baik pada tahun tertentu mendukung kinerja penyelenggara negara di 15 entitis pemerintah provinsi/kabupaten/kota di Provinsi Kalimantan Tengah untuk menyusun laporan keuangan yang lebih baik sehingga hasil penilaian opini pada tahun berikutnya meningkat. Perkembangan yang positif dan signifikan $($ sig < 0,05) untuk opini LKPD ini terjadi dari tahun 2007 ke tahun 2008, tahun 2010, dan tahun 2011 yang masing-masing ditunjukkan oleh nilai PC 0,635 dengan sig 0,011, nilai PC 0,602 dengan sig 0,018, dan nilai PC 0,533 dengan sig 0,041.

Hal ini relevan dengan hasil pemantuan BPK, dimana ada 5 entitas pemerintah daerah di Kalimantan Tengah yang mendapat opini Wajar Dengan Pengecualian (WDP) pada tahun 2007, kemudian jumlah tersebut berkembang menjadi 7 entitas pemerintah daerah di tahun 2010 dan 9 entitas pemerintah daerah di tahun 2011. Untuk saat ini, opini Wajar Dengan Pengecualian (WDP) merupakan opini yang paling baik yang didapat oleh entitas pemerintah daerah di Kalimantan Tengah. Selama periode tahun 2007 - 2011, ke15 entitas pemerintah daerah di Kalimantan Tengah belum pernah memperoleh opini Wajar Tanpa Pengecualian (WTP).

Pada Tabel 4 dan Tabel 5 dijelaskan, hal ini cukup wajar karena berbagai keterbatasan yang terjadi dalam penyiapan laporan keuangan tersebut, terutama terkait dengan kualitas SDM di entitas pemerintah daerah di di Kalimantan Tengah. Mardiasmo (2006) menyatakan bahwa penyimpangan pelaporan keuangan tidak hanya dipengaruhi oleh faktor kesengajaan untuk bertindak korup, tetapi juga oleh ketindaktahuan dan keterbatasan kualitas SDM. 
Tabel 4. Perkembangan opini LKPD di Provinsi Kalimantan Tengah

\begin{tabular}{llrrrrr}
\hline & & X1 (2007) & X2 (2008) & X3 (2009) & X4 (2010) & X5 (2011) \\
\hline X1 (2007) & Pearson Correlation & 1 &, $635^{*}$ &, 182 &, $602^{*}$ &, $533^{*}$ \\
& Sig. (2-tailed) & &, 011 &, 515 &, 018 &, 041 \\
& N & 15 & 15 & 15 & 15 & 15 \\
X2 (2008) & Pearson Correlation &, $635^{*}$ & 1 &, 415 &, $539^{*}$ &, 462 \\
& Sig. (2-tailed) &, 011 & &, 124 &, 038 &, 083 \\
& N & 15 & 15 & 15 & 15 & 15 \\
X3 (2009) & Pearson Correlation &, 182 &, 415 & 1 &, 145 &, 119 \\
& Sig. (2-tailed) &, 515 &, 124 & &, 607 &, 673 \\
& N & 15 & 15 & 15 & 15 & 15 \\
X4 (2010) & Pearson Correlation &, $602^{*}$ &, $539^{*}$ &, 145 & 1 &, $879^{* *}$ \\
& Sig. (2-tailed) &, 018 &, 038 &, 607 & &, 000 \\
& N & 15 & 15 & 15 & 15 & 15 \\
X5 (2011) & Pearson Correlation &, $533^{*}$ &, 462 &, 119 &, $879^{* *}$ & 1 \\
& Sig. (2-tailed) &, 041 &, 083 &, 673 &, 000 & \\
& N & 15 & 15 & 15 & 15 & 15 \\
*. Correlation is significant at the 0.05 level (2-tailed). & & & \\
**. Correlation is significant at the 0.01 level (2-tailed). & \multicolumn{5}{c}{} \\
\hline
\end{tabular}

Tabel 5. Opini LKPD di Wilayah Provinsi Kalimantan Tengah Tahun 2007 - 2011

\begin{tabular}{rlccccc}
\hline \multirow{2}{*}{ No } & \multicolumn{1}{c}{$\begin{array}{c}\text { Entitas } \\
\text { Pemerintah Daerah }\end{array}$} & \multicolumn{5}{c}{ Opini LKPD } \\
\cline { 2 - 6 } & \multicolumn{1}{c}{2007} & 2008 & 2009 & 2010 & 2011 \\
\hline 1 & Prov. Kalimantan Tengah & TW & WDP & TW & WDP & WDP \\
2 & Kab. Barito Selatan & TMP & TW & TW & TW & TMP \\
3 & Kab. Barito Timur & TMP & TMP & TW & TMP & TMP \\
4 & Kab. Barito Utara & TW & TW & TW & TMP & TMP \\
5 & Kab. Gunung Mas & WDP & TW & TW & WDP & WDP \\
6 & Kab. Kapuas & TW & TW & WDP & WDP & WDP \\
7 & Kab. Katingan & TW & WDP & WDP & TMP & TMP \\
8 & Kab. Kotawaringin Barat & WDP & WDP & TW & WDP & WDP \\
9 & Kab. Kotawaringin Timur & TW & TW & TW & TW & WDP \\
10 & Kab. Lamandau & TW & TW & TW & WDP & WDP \\
11 & Kab. Murung Raya & TMP & TW & TW & TW & WDP \\
12 & Kab. Pulang Pisau & WDP & TW & TW & TW & TW \\
13 & Kab. Seruyan & TMP & TMP & TMP & TMP & TMP \\
14 & Kab. Sukamara & WDP & WDP & TW & WDP & WDP \\
15 & Kota Palangka Raya & WDP & WDP & TW & WDP & WDP \\
\hline Sind & & & & & \\
\end{tabular}

Sumber: BPK (2012b)

Perkembangan opini LKPD dari tahun 2008 ke tahun 2010 juga bersifat positif kuat dan signifikan yang ditunjukkan oleh nilai PC 0,539 (range < 0,5 - 0,75) dengan sig < 0,05, yaitu 0,038 . Hal ini menujukkan bahwa hasil penilaian opini LKPD yang baik pada tahun 2008 mendorong penyiapan laporan keuangan yang baik pada tahun 2010 sehingga opini LKPD-nya lebih baik. Pada tahun 2008, ada 5 entitas pemerintah daerah di Kalimantan Tengah yang mendapat opini Wajar Dengan Pengecualian (WDP), sedangkan pada tahun 
2010 jumlahnya meningkat menjadi 7 entitas pemerintah daerah. Pada tahun 2011, yang mendapat opini Wajar Dengan Pengecualian (WDP) meningkat lagi menjadi 9 entitas pemerintah daerah di Kalimantan Tengah ( $\mathrm{PC}=0,879$ dengan sig $<0,05$, yaitu 0,000).

Perkembangan Opini LKPD di Provinsi Kalimantan Timur. Perkembangan opini atas Laporan Keuangan Pemerintah Daerah (LKPD) di Provinsi Kalimantan Tengah disajikan pada Tabel 6. Seperti halnya di Kalimantan Barat dan Kalimantan Tengah, kerterkaitan antar opini LKPD selama periode tahun 2007 - 2011 di Kalimantan Timur, semuanya bersifat positif yang ditunjukkan oleh nilai pearson correlation $(\mathrm{PC})>0,000$. Hal ini menunjukkan hasil penilaian opini LKPD selalu membaik dari tahun ke tahun pada 15 entitis pemerintah provinsi/kabupaten/kota di Provinsi Kalimantan Timur (Tabel 6).

Tabel 6. Perkembangan opini LKPD di Provinsi Kalimantan Timur

\begin{tabular}{|c|c|c|c|c|c|c|}
\hline & & X1 (2007) & X2 (2008) & X3 (2009) & X4 (2010) & X5 (2011) \\
\hline \multirow[t]{3}{*}{$\overline{X 1}(2007)$} & Pearson Correlation & 1 & $603^{*}$ & 402 & ,611* &, $701^{* *}$ \\
\hline & Sig. (2-tailed) & & 017 & 138 & ,016 & ,004 \\
\hline & $\mathrm{N}$ & 15 & 15 & 15 & 15 & 15 \\
\hline \multirow[t]{3}{*}{ X2 (2008) } & Pearson Correlation & ,603* & 1 &, $767^{* *}$ &, $727^{* *}$ & ,839** \\
\hline & Sig. (2-tailed) & 017 & & ,001 & ,002 & ,000 \\
\hline & $\mathrm{N}$ & 15 & 15 & 15 & 15 & 15 \\
\hline \multirow[t]{3}{*}{ X3 (2009) } & Pearson Correlation & ,402 &, $767^{* *}$ & 1 & $665^{* *}$ &, $564^{*}$ \\
\hline & Sig. (2-tailed) & 138 & ,001 & & ,007 & ,029 \\
\hline & $\mathrm{N}$ & 15 & 15 & 15 & 15 & 15 \\
\hline \multirow[t]{3}{*}{ X4 (2010) } & Pearson Correlation & ,611* &, $727^{* *}$ & ,665 $5^{* *}$ & 1 & ,836 \\
\hline & Sig. (2-tailed) & ,016 & ,002 & ,007 & & 000 \\
\hline & $\mathrm{N}$ & 15 & 15 & 15 & 15 & 15 \\
\hline \multirow[t]{3}{*}{ X5 (2011) } & Pearson Correlation &, $701^{* *}$ & ,839** &, $564^{*}$ &, $836^{* *}$ & 1 \\
\hline & Sig. (2-tailed) & ,004 & ,000 & ,029 & ,000 & \\
\hline & $\mathrm{N}$ & 15 & 15 & 15 & 15 & 15 \\
\hline
\end{tabular}

Perkembangan positif kuat dan signifikan (sig < 0,05) untuk opini LKPD ini terjadi dari tahun 2007 ke tahun 2008, tahun 2010, dan tahun 2011 yang masing-masing ditunjukkan oleh nilai PC 0,603 dengan sig 0,017, nilai PC 0,611 dengan sig 0,016, dan nilai PC 0,701 dengan sig 0,004. Untuk tahun 2007 ke tahun 2008, hal ini ditunjukkan oleh entitas pemerintah daerah di Kalimantan Timur yang mendapat opini Wajar Dengan Pengecualian (WDP) dari 0 (tidak ada) untuk LKPD tahun 2007 menjadi 5 entitas Pemerintah Kabupaten/Kota untuk LKPD tahun 2008, yaitu pemerintah Kabupaten Nunukan, Kabupaten Penajam Paser Utara, Kota Balikpapan, Kota Bontang, dan Kota Tarakan (Tabel 6). Menurut PEMDA Provinsi Kalimantan Timur (2011), peningkatan signifikan jumlah entitas pemerintah daerah yang mendapat opini Dengan Pengecualian (WDP) untuk LKPD tahun 2008 diduga karena adanya beberapa pembekalan kepada petugas yang menangani laporan keuangan di Kalimantan Timur dan dorongan pemerintah daerah terkait untuk meningkat kinerja pengelolaan keuangannya.

Entitas Pemerintah Provinsi/Kabupaten/Kota di Kalimantan Timur yang mendapat opini Wajar Dengan Pengecualian (WDP) untuk LKPD tahun 2010 ada 5 entitas, yaitu Pemerintah Provinsi Kalimantan Timur, Kabupaten Berau, Kota Balikpapan, Kota 
Bontang, dan Kota Tarakan, sedangkan untuk LKPD tahun 2010 ada 9 entitas, yaitu Pemerintah Provinsi Kalimantan Timur, Kabupaten Berau, Kabupaten Kutai Kartanegara, Kabupaten Nunukan, Kabupaten Paser, Kabupaten Penajam Paser Utara, Kota Balikpapan, Kota Bontang, dan Kota Tarakan. Hal ini mengdnikasikan bahwa penyelenggara negara di 15 entitas Pemerintah Provinsi/Kabupaten/Kota di Kalimantan Timur telah lebih baik dan semangit mengerti dalam penyusunan laporan kuangannya, sehingga diberi opini yang baik menurut penilaian BPK. Rahmanti dan Prastiwi (2011) menyatakan bahwa opini yang diberikan dalam penilaian LKPD mengacu kepada format penilaian yang standar yang diatur menurut undang-undang, dimana opini yang lebih baik hanya terjadi bila LKPD yang diberikan semakin akuntabel.

Tabel 7. Opini LKPD di Wilayah Provinsi Kalimantan Timur Tahun 2007 - 2011

\begin{tabular}{clccccc}
\hline \multirow{2}{*}{ NO } & \multicolumn{1}{c}{ ENTITAS } & \multicolumn{5}{c}{ OPINI LKPD } \\
\cline { 3 - 7 } & \multicolumn{1}{c}{ PEMERINTAH DAERAH } & 2007 & 2008 & 2009 & 2010 & 2011 \\
\hline \multirow{2}{*}{ LKPD } & Provinsi Kalimantan Timur & 14 & 14 & 15 & 15 & 15 \\
2 & Kabupaten Berau & TW & TW & TW & WDP & WDP \\
3 & Kabupaten Bulungan & TW & TW & TW & WDP & WDP \\
4 & Kabupaten Kutai Barat & TW & TW & TW & TW & TW \\
5 & Kabupaten Kutai Kartanegara & TW & TW & TW & TW & WDP \\
6 & Kabupaten Kutai Timur & TMP & TMP & TMP & TMP & TMP \\
7 & Kabupaten Malinau & TMP & TMP & TMP & TW & TW \\
8 & Kabupaten Nunukan & TMP & TW & WDP & TW & TW \\
9 & Kabupaten Paser & TW & WDP & TW & TW & WDP \\
10 & Kabupaten Penajam Paser Utara & TW & TW & TW & TW & WDP \\
11 & Kabupaten Tana Tidung & TMP & WDP & TW & TW & WDP \\
12 & Kota Balikpapan & - & - & TMP & TMP & TMP \\
13 & Kota Bontang & TW & WDP & WDP & WDP & WDP \\
14 & Kota Samarinda & TW & WDP & WDP & WDP & WDP \\
15 & Kota Tarakan & TMP & TMP & TW & TMP & TMP \\
\hline
\end{tabular}

Sumber: BPK (2011) dan BPK (2012c)

Perkembangan positif dan signifikan (sig < 0,05) untuk opini LKPD ini juga terjadi dari tahun 2008 ke tahun 2009, tahun 2010, dan tahun 2011 yang masing-masing ditunjukkan oleh nilai PC 0,767 dengan sig < 0,001, nilai PC 0,727 dengan sig 0,002, dan nilai PC 0,839 dengan sig 0,000. Hal yang sama juga terjadi dari tahun 209 ke tahun 2010 dan tahun 2011 yang masing-masing ditunjukkan oleh nilai PC 0,665 dengan sig < 0,007, serta nilai PC 0,564 dengan sig 0,029. Dibanding tahun 2009, yang LKPD-nay mendapat opini Wajar Dengan Pengecualian (WDP) ada 4 entitas Pemerintah Provinsi/Kabupaten/Kota, pada tahun 2010 dan tahun 2011 yang mendapat opini Wajar Dengan Pengecualian (WDP) lebih tinggi, yaitu masing-masing 5 entitas dan 9 entitas (Tabel 7). Suwanda ( 2013) menyatakan bahwa opini Wajar Dengan Pengecualian (WDP) merupakan hasil penilaian LKPD yang banyak ditargetkan pemerintah daerah saat ini karena lebih realitas dicapai untuk kondisi saat ini, meskipun itu bukan hasil penilaian terbaik. 
Pemetaan Opini Laporan Keuangan Pemerintah Daerah. Bila Laporan Keuangan Pemerintah Daerah (LKPD) dipetakan berdasarkan nilai opininya, maka terlihat pola penyebaran hasil penilaian LKPD setiap entitas Pemerintah Provinsi/Kabupaten/Kota setiap tahunnya. Pola penyebaran tersebut merupakan gambaran dari keragamanan kinerja pemerintah daerah dalam hal pengelolaan keuangan negara yang diamanatkan kepadanya. Gambar 2 menyajikan hasil pemetaan markers radar terhadap opini LKPD tahun 2007 2011 di wilayah Kalimantan Barat, Kalimantan Tengah, dan Kalimantan Timur. Semakin lebar jangkauan radar pada peta, semakin meningkatkan kinerja pemerintah daerah dalam pengelolaan keuangan.

Berdasarkan Gambar 2, pada tahun 2007 - 2009, peta opini LKPD di Kalimantan Barat terlihat agak zig-zag sempit dan sebagian besar berada lingkaran kedua peta radar. Kemudian pada tahun 2010, lebih stabil pada lingkaran ketiga peta radar, dan hanya ada dua entiitas pemerintah daerah yang berada pada lingkaran kedua peta radar. Sedangkan pada tahun 2011, sebagian besar entitas pemerintah daerah (13 entitas) berada pada lingkaran ketiga, ada satu entitas yang berada pada lingkaran kedua, dan ada satu entitas yang berada pada lingkaran keempat. Jangkauan radar pada peta semakin lebar dari tahun ke tahun, terutama terjadi pada tahun 2010 dan 2011. Hal ini menunjukkan bahwa perkembangan opini LKPD semakin baik dari tahun ke tahun, dan hal ini relatif seragam dan kompok terjadi di wilayah Kalimantan Barat. Menurut Milal (2013) dan Siregar (2012), kekompokan dan kesamaan persepsi entitas pemerintah daerah dalam penyelenggaraan pemerintahan akan mempermudah pemerataan pembangunan di suatu wilayah, mengeliminir konflik, dan mencegah sentimen kedaerahan.

Berbeda dengan Kalimantan Barat, jangkauan radar pada peta untuk Kalimantan Tengah dan Kalimantan Timur tetap zig-zag hingga tahun 2011. Bahkan ada beberapa entitas pemerintah daerah yang menyempit jangkauan radarnya dari tahun sebelumnya. Pada tahun 2011, cukup banyak entitas pemerintah daerah yang berada pada lingkaran ketiga peta radar, yaitu masing-masing 10 entitas di wilayah Kalimantan Tengah dan Kalimantan Timur, serta tidak ada entitas pemerintah daerah yang berada pada lingkaran keempat peta radar. Hal ini menunjukkan bahwa disamping opini LKPD lebih beragam antar entitas di kedua wilayah ini, juga kinerja pemerintah daerahnya dalam pengelolaan keuangan lebih rendah dibandingkan dengan Kalimantan Barat. Menurut Rahmanti dan Prastiwi (2011), perbedaan kinerja terkait pengelolaan keuangan di suatu wilayah dapat disebabkan perbedaan standar rekrutmen SDM pengelola, pembinaan yang parsial di wilayah, dan perbedaan orientasi entitas pemerintah daerah dalam realisasi anggaran. BPK (2007b) menyatakan bahwa Undang-Undang Nomor 32 Tahun 2004 memberi ruang kepada pemerintah daerah untuk mengatur orientasi kegiatan pembangunan di daerah masing-masing.

Status Tindak Lanjut Rekomendasi Hasil Pemeriksaan BPK Periode Tahun 2008 2012 di Provinsi Kalimantan Barat. Pada periode tahun 2008 - 2012, total rekomendasi BPK atas Laporan Keunagan Pemerintah Daerah (LKPD) pada 15 entitas Pemerintah Provinsi/Kabupaten/Kota di Kalimantan Barat mencapai 5.058 rekomendasi kasus dengan nilai sekitar Rp 233,347 milyar. Status tindak lanjut rekomendasi BPK pada 15 pentitas Pemerintah Provinsi/Kabupaten/Kota di Kalimantan Barat ini disajikan pada Tabel 3. Status tindak lanjut rekomendasi BPK tersebut terdiri dari telah ditindaklanjuti sesuai rekomendasi, dalam proses (belum selesai tindak lanjutnya), belum ditindaklanjuti, dan tidak bisa ditindaklanjuti. 


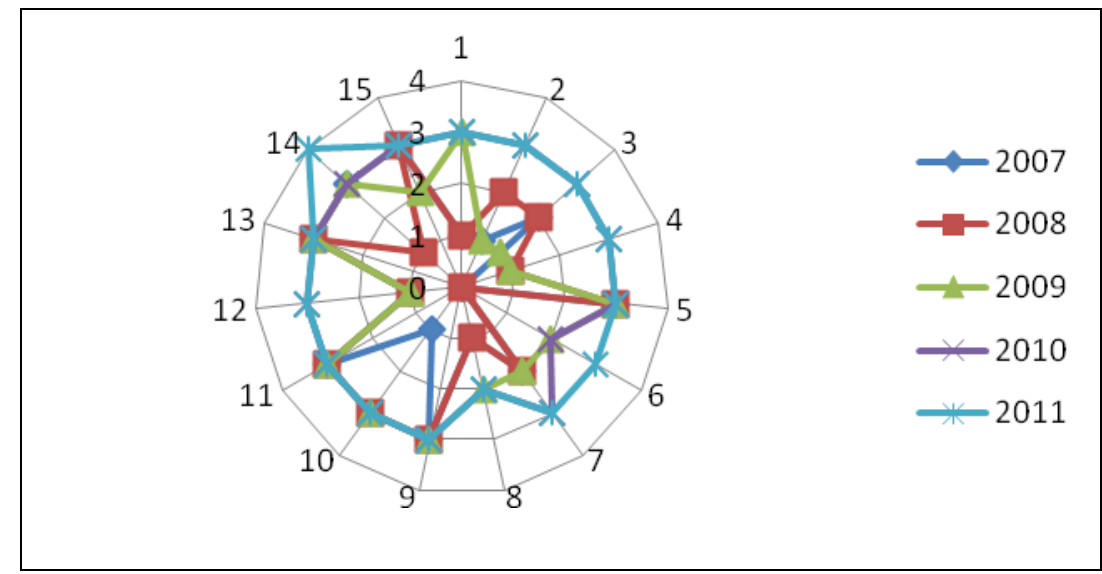

(a) Wilayah Provinsi Kalimantan Barat

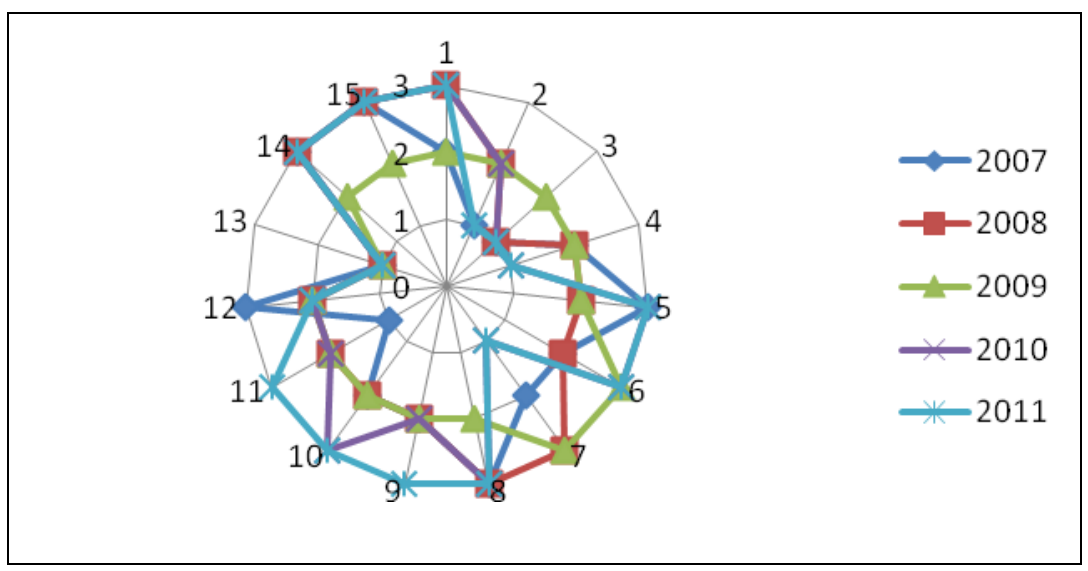

(b) Wilayah Provinsi Kalimantan Tengah

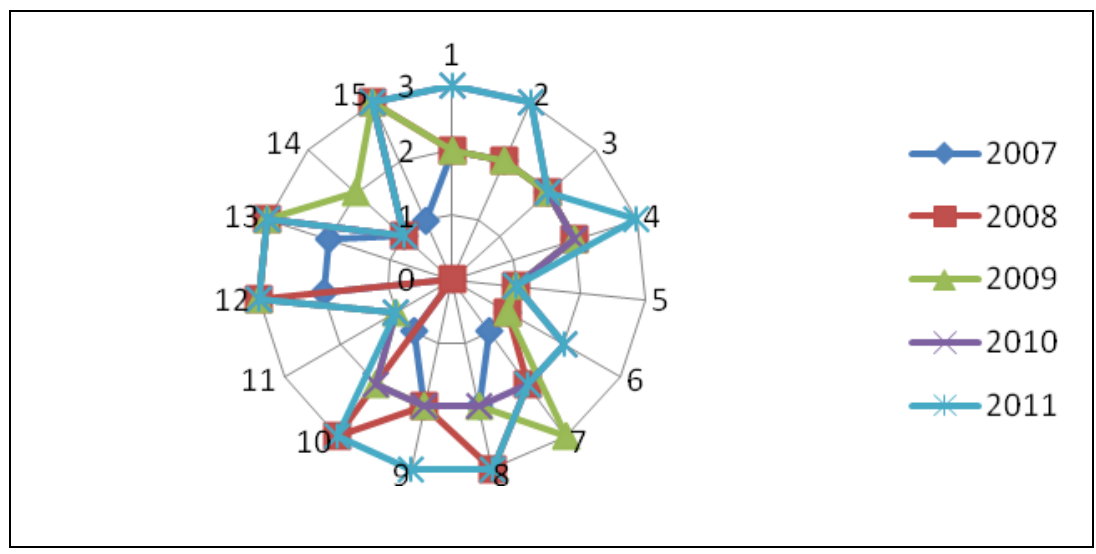

(c) Wilayah Provinsi Kalimantan Timur

Gambar 2. Peta markers radar dari opini LKPD periode tahun 2007 - 2011 


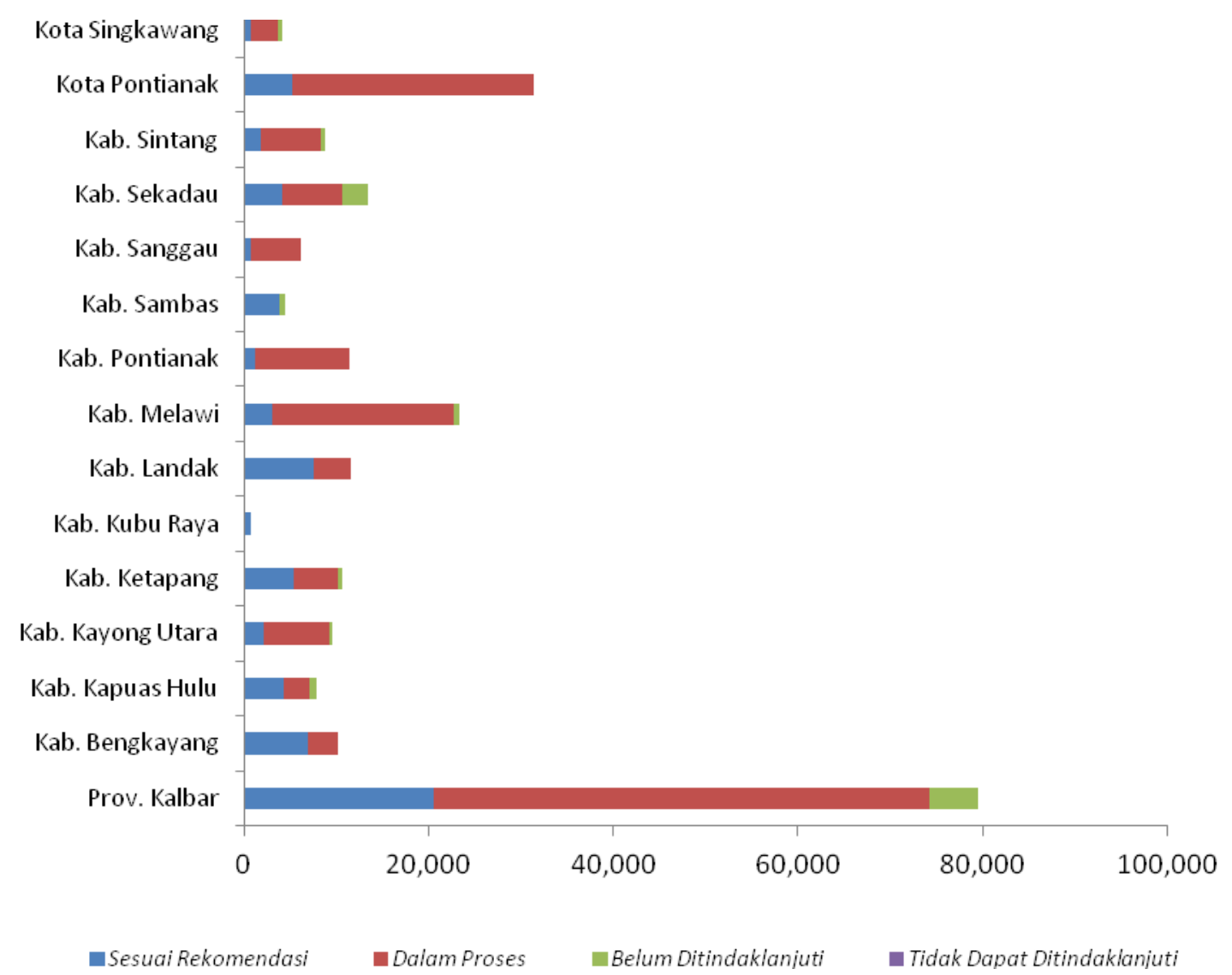

Gambar 3. Status tindak lanjut rekomendasi hasil pemeriksaan BPK periode tahun 2008 2012 di Provinsi Kalimantan Barat (berdasarkan nilai dalam juta rupiah)

Berdasarkan Gambar 3, tindak lanjut hasil pemeriksaan BPK yang sesuai rekomendasi, paling banyak terjadi di Pemerintah Provinsi Kalimantan Barat, yaitu mencapai 489 kasus dengan nilai Rp 20,483 milyar. Hal ini terjadi diduga karena sarana dan prasarana pendukung serta kualitas SDM yang relatif baik pada Pemerintah Provinsi Kalimantan Barat sehingga responsif terhadap rekomendasi yang diberikan. Menurut Suwanda (2013), kemampuan pemerintah daerah untuk menindaklanjuti rekomendasi yang diberikan oleh auditor sangat dipengaruhi oleh ketersediaan sarana untuk menunjukkan pelaporan yang lebih baik, kualitas dan kapasitas SDM, serta persepsi terhadap pelaporan keuangan akuntabel.

Pemerintah Kabupaten Bengkayang, Kabupaten Landak, dan Kabupaten Kubu Raya juga telah banyak menindaklanjuti sesuai rekomendasi tekait hasil pemeriksaan BPK atas LKPD-nya pada periode tahun 2008 - 2012. Jumlah kasus yang telah ditindaklanjuti sesuai rekomendasi di ketiga entitas pemerintah daerah ini mencapai 138 kasus dengan nilai Rp 6,980 milyar untuk Pemerintah Kabupaten Bengkayang, 228 kasus dengan nilai Rp 7,497 milyar untuk Pemerintah Kabupaten Landak, dan 91 kasus dengan nilai Rp 759 juta untuk Pemerintah Kabupaten Kubu Raya. Secara kuantitatif, kasus yang telah ditindaklanjuti sesuai rekomendasi di Pemerintah Kabupaten Kubu Raya tidak terlalu tinggi, tetapi bila dibandingkan dengan jumlah kasus yang belum ditindak lanjuti (hanya 4 kasus), maka tindak lanjut sesuai rekomendasi tersebut termasuk berprogress baik. 
Menurut Madril (2010), keberhasilan tindak lanjut hasil pemeriksaan sangat ditentukan oleh seberapa banyak uang negara yang berhasil dikembalikan dan seberapa banyak yang belum atau tidak dikembalikan.

Entitas pemerintah daerah dengan tindak lanjut sesuai rekomendasi yang rendah/sedikit terkait hasil pemeriksaan BPK adalah Pemerintah Kabupaten Melawi dan Pemerintah Kabupaten Pontianak. Jumlah kasus yang tindaklanjuti sesuai rekomendasi di Pemerintah Kabupaten Melawi mencapai 106 kasus dengan nilai Rp 3 milyar, dan di Pemerintah Kabupaten Pontianak mencapai 183 kasus dengan nilai Rp 1,223 milyar. Untuk Kabupaten Melawi, hal terjadi duga karena lambatnya Pemerintah Daerah terkait merespon rekomendasi hasil pemeriksaan, sehingga pada waktu pemantauan dilakukan belum banyak yang selesai. Hal ini juga terlihat dari jumlah kasus yang masih ditangani (dalam proses) pada saat pemantauan dilakukan pada 30 Juni 2013 yang mencapai 145 kasus dengan nilai 19,791 milyar. Sedangkan hasil pemeriksaan BPK yang belum ditindaklanjuti oleh Pemerintah Kabupaten Melawi hanya 82 kasus (nilai Rp 484 juta).

Secara keseluruhan, dari 5.058 rekomendasi hasil pemeriksaan BPK atas LKPD periode 2008 - 2012, telah ditindaklanjuti dengan status sesuai rekomendasi sekitar 3.007 kasus (59,45\%) dengan nilai Rp 68,336 milyar (29,29\%), status dalam proses tindak lanjut sekitar 1.546 kasus (30,57\%) dengan nilai Rp153,400 milyar (65,74\%), status belum ditindaklanjuti sekitar 506 kasus (10,00\%) dengan nilai Rp 11,382 milyar (4,88\%), dan status tidak bisa ditindakdilanjuti tidak ada (0 kasus). Dari total nilai rekomendasi kasus, jumlah kerugian negara yang berhasil dikembalikan dan di setor ke ke Kas Negara mencapai Rp 69,825 milyar atau 29,92\%.

Status Tindak Lanjut Rekomendasi Hasil Pemeriksaan BPK Periode Tahun 2008 2012 di Provinsi Kalimantan Tengah. Mengacu hasil pemeriksaan BPK atas Laporan Keuangan Pemerintah Daerah (LKPD) di 15 entitas Pemerintah Provinsi/Kabupaten/Kota di Kalimantan Tengah, ada 6.152 rekomendasi kasus dengan nilai Rp 365,26 milyar yang perlu ditindaklanjuti. Tindak lanjut hasil pemeriksaan BPK tersebut merupakan upaya penting untuk mengembalikan kerugian keuangan negara atas penyimpangan pengelolaan yang terjadi selama Ini. Tindak lanjut sesuai rekomendasi BPK sangat diharapkan untuk optimalisasi pengelolaan keuangan secara transparan dan terbebas dari penyimpangan untuk memperkaya kelompok tertentu. Gambar 4 menyajikan status tindak lanjut rekomendasi BPK atas LKPD pada 15 entitas Pemerintah Provinsi/Kabupaten/Kota di Kalimantan Tengah yang dianalisis.

Mengacu kapada Gambar 4, Pemerintah Provinsi Kalimantan Tengah telah dapat menindaklanjuti hasil pemeriksaan BPK sesuai rekomendasi dengan jumlah paling banyak sekitar 35.161 kasus dengan nilai Rp 35,161 milyar. Pemerintah Kabupaten Kobar juga termasuk banyak menindaklanjuti sesuai rekomendasi terkait hasil pemeriksaan BPk, yaitu masing-masing mencapai 402 kasus dengan nilai Rp 17,564 milyar.

Untuk Kabupaten Kobar, hal ini diduga karena Pemerintah Daerah terkait telah menerapkan sistem pengawasan terpadu dalam pengelolaan keuangannya, dimana setiap temuan kejanggalan dimonitor dan instansi terkait di daerah tersebut terpaju untuk segera mengklarifikasi dan menyelesaikannya. Menurut BPKP (2010), disamping dapat meminimalisir penyimpangan pengelolaan, pengawasan terpadu juga mempercepat penyelesaian hasil pemeriksaan dan monitoring oleh lembaga pemeriksa keuangan.

Jumlah paling sedikit untuk tindaklanjuti sesuai rekomendasi terjadi di Kabupaten Barito Utara dan Kota Palangkaraya. Dari hasil observasi yang dilakukan, Pemerintah 
Kabupaten Barito Utara dan Pemerintah Kota Palangkaraya berhasil menindaklanjuti sesui rekomendasi terkait hasil pemeriksaan BPK masing-masing sekitar 356 kasus dengan nilai Rp 2,03 milyar dan 171 kasus dengan nilai 3,573 milyar.

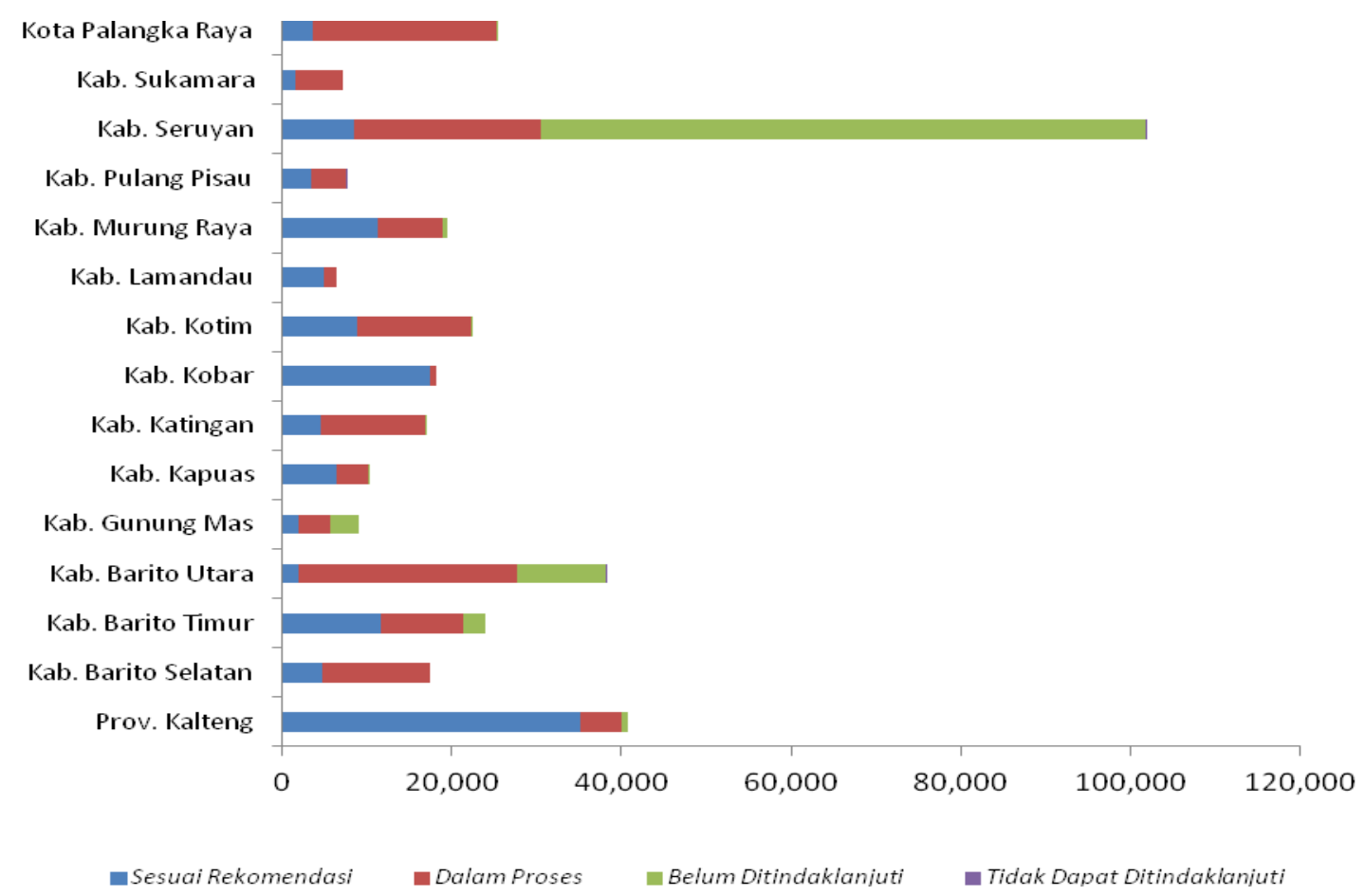

Gambar 4. Status tindak lanjut rekomendasi hasil pemeriksaan BPK periode tahun 2008 2012 di Provinsi Kalimantan Tengah (berdasarkan nilai dalam juta rupiah)

Kasus penyimpangan pengelolaan keuangan di Kabupaten Barito Utara umumnya bernilai kecil dan umumnya terjadi pada kegiatan yang bersifat kajian dan kegiatan pengadaan barang dengan sistem penunjukan langsung (PEMDA Provinsi Kalimantan Tengah, 2013). Sedangkan untuk Kota Palangkaraya, umumnya terjadi pada kegiatan operasional langsung Pemerintah Daerah.

Secara umum, dari total 6.152 rekomendasi BPK selama periode tahun 2008 - 2012 pada 15 entitas Pemerintah Provinsi/Kabupaten/Kota di Kalimantan Tengah, ditindaklanjuti dengan status sesuai rekomendasi sekitar 3.800 kasus $(61,77 \%$ dari total rekomendasi) dengan nilai Rp126,569 milyar (34,65\%), status dalam proses tindak lanjut sekitar 1.469 kasus (23,88\%) dengan nilai Rp149,284 milyar (40,87\%), status belum ditindaklanjuti sekitar 877 kasus (14,26\%) dengan nilai Rp 89,110 milyar (24,40\%), dan status tidak dapat ditindaklanjuti 6 kasus (0,1\%) dengan nilai Rp 300 juta (0,08\%). Sedangkan jumlah kerugian yang telah dikembalikan dan di setro ke Kas Negara mencapai Rp 127,149 milyar atau 34,81\% dari total nilai rekomendasi BPK.

Status Tindak Lanjut Rekomendasi Hasil Pemeriksaan BPK Periode Tahun 2008 2012 di Provinsi Kalimantan Timur. Untuk Provinsi Kalimantan Timur, Badan Pemeriksa Keuangan (BPK) merekomendasikan sekitar 4.249 kasus dengan nilai Rp1.084,85 milyar dan USD 10,380.32 ribu yang perlu ditindaklanjuti terkait pengelolaan keuangan negara di 15 entitas Pemerintah Provinsi/Kabupaten/Kota di Kalimantan 
Tengah. Perkembangan tindak lanjut hasil rekomendasi hasil pemeriksaan BPK periode tahun 2008 - 2012 di 15 entitas Pemerintah Provinsi/Kabupaten/Kota di Kalimantan Tengah ini disajikan pada Gambar 5. Berdasarkan Gambar 5, tindak lanjut sesuai rekomendasi belum banyak terjadi pada 15 entitas Pemerintah Daerah yang dikaji dalam penelitian ini terkait LKPD di Kalimantan Tengah. Namun demikian, capaian paling tinggi terjadi di Kabupaten Kutai Kartanegara (kukar), yaitu 155 kasus dengan nilai 42,750 milyar.

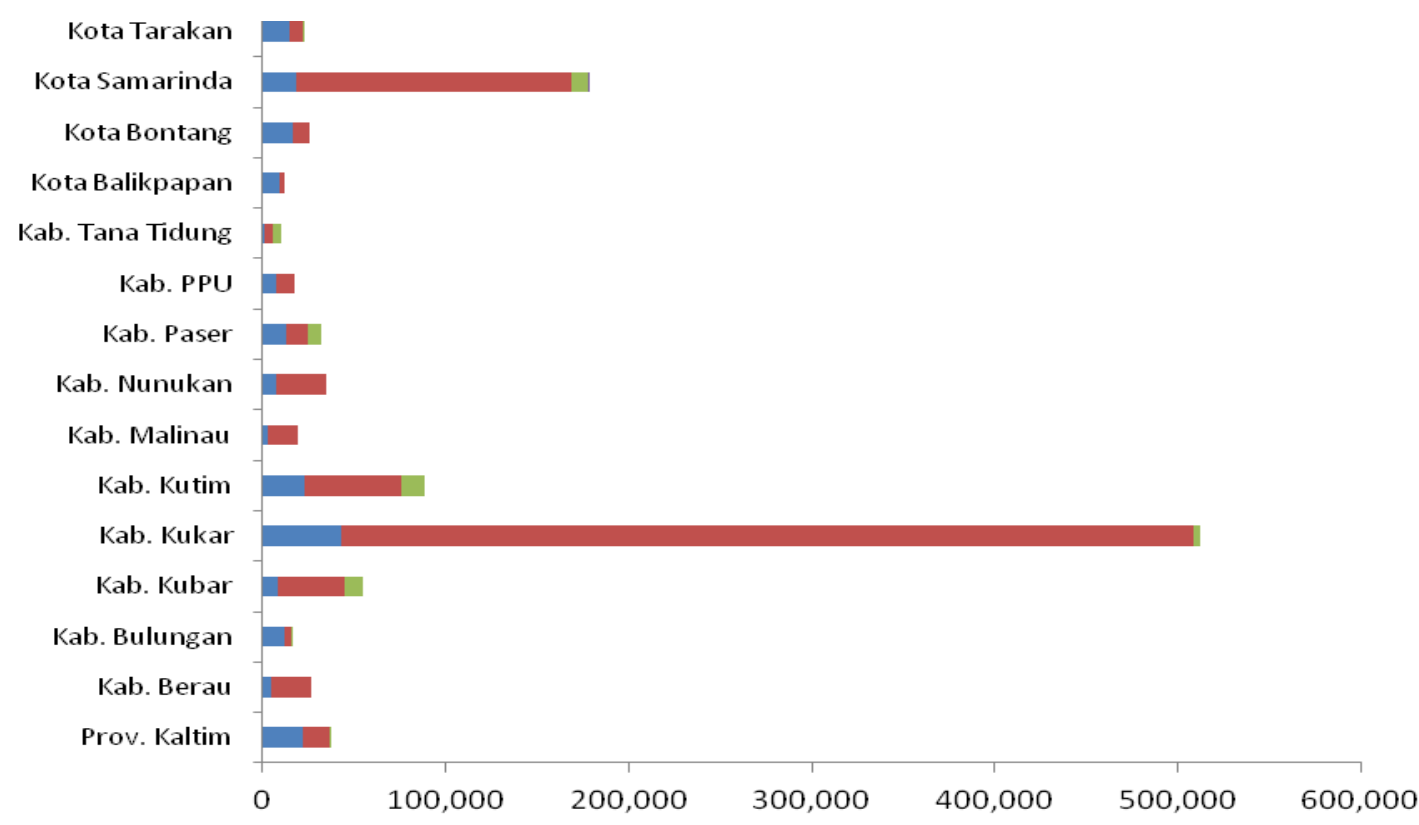

-SesuaiRekomendasi $\quad$ DalamProses Belum Ditindaklanjuti $\quad$ Tidak Dapat Ditindaklanjuti

Gambar 5. Status tindak lanjut rekomendasi hasil pemeriksaan BPK periode tahun 2008 2012 di Provinsi Kalimantan Timur (berdasarkan nilai dalam juta rupiah)

Jumlah kasus yang masih dalam proses tindak lanjut paling banyak terjadi di Kabupaten Kutai Kartanegara (Kukar) dan Kota Samarinda, yaitu masing-masing 281 kasus dengan nilai 465,555 milyar dan 149 kasus dengan 150,340 milyar (Gambar 4). Hal ini memberi indikasi bahwa rekomendasi hasil pemeriksaan BPK telah diresponden dengan baik oleh Pemerintah Kabupaten Kutai Kartanegara (Kukar) dan Pemerintah Kota Samarinda, yang walaupan dalam pelaksanaannya belum dapat memberikan hasil yang optimal sesuai jadwal. Menurut PEMDA Provinsi Kalimantan Timur (2011), kelambatan tersebut disebabkan oleh kondisi geografis daerah yang luas sehingga koordinasi dan pengumpulan data pendukung penggunaan keuangan tersebut tidak bisa cepat. Sedangkan menurut Arens, et. al (2003), pengunaaan keuangan negara terutama untuk kegiatan-kegiatan yang bersifat fisik membutuhkan pengecekan dan koordinasi dengan unit teknis di lapangan.

Hasil pemeriksaan BPK yang belum ditindaklanjuti tidak terlalu banyak di 15 entitas Pemerintah Provinsi/Kabupaten/Kota di Kalimantan Tengah. Untuk Kabupaten Barito Selatan dan Kabupaten Lamandu, yang belum ditindak lanjuti hanya sekitar 7 kasus dan 5 kasus. Hal ini menunjukkan bahwa di kedua kabupaten ini, tindak lanjut hasil pemeriksaan BPK telah direspon dan dilaksanakan dengan baik oleh Pemerintah Kabupaten Barito 
Selatan dan Pemerintah Kabupaten Lamandu. Suroso (2010), menyatakan bahwa pelaksanaan tindak lanjut hasil pemeriksaan auditor atau lembaga pemeriksa keuangan resmi meskipun geografis wilayah relatif sulit merupakan bentuk ketanggapan dan kepedulian tinggi dari Pemerintah Daerah terkait dalam pengelolaan keuangan negara yang diamanatkan kepadanya.

Rekemondasi BPK yang tidak dapat ditindaklanjuti hanya terjadi di Kabupaten Barito Utara, Kabupaten Pulau Pisau, dan Kabupaten Seruyan. Menurut PEMDA Provinsi Kalimantan Timur (2011) dan Mardiasmo (2006), hal ini umumnya terjadi karena adaya musibah dalam pelaksaan proyek yang didanai oleh keuangan negara terutama yang dikucurkan melalui APBD ketiga daerah tersebut, sehingga pertanggungjawaban sulit dilakukan. Penjaminan proyek terkadang sulit dilakukan di daerah karena terbatasnya lembaga penjamin yang berkompeten di daerah kabupaten tersebut. Secara umum, dari 4.249 kasus (nilai Rp1.084,85 milyar dan USD10,380.32 ribu) yang direkomendasikan BPK di Provinsi Kalimantan Timur, ditindaklanjuti dengan status sesuai rekomendasi sekitar 2.350 kasus (55,31\% dari total rekomendasi) dengan nilai Rp202,01 milyar dan USD1,262.72 ribu, status dalam proses tindak lanjut sekitar 1494 kasus (35,16\%)dengan nilai Rp 833,11 milyar (76,79\%) dan USD9,117.59 ribu, status belum ditindaklanjuti sekitar 402 kasus (9,46\%) dengan nilai Rp 49,58 milyar (4,57\%), dan status tidak dapat ditindaklanjuti sekitar 3 kasus (0,07\% dari total rekomendasi) dengan nilai Rp 0,15 milyar $(0,02 \%)$. Sedangkan jumlah kerugian negara yang berhasil diselamatkan dan telah disetor ke Kas Negara mencapai Rp 202,89 milyar atau 18,70\% dari total nilai rekomendasi.

\section{PENUTUP}

Simpulan. Di Kalimantan Barat, opini LKPD mengalami perkembangan positif dan signifikan (sig < 0,05) dari tahun 2007 ke tahun 2008 dan 2009 yaitu masing-masing ditunjukkan oleh nilai PC 0,712 dengan sig 0,03 dan nilai PC 0,549 dengan sig 0,034. Sedangkan di Kalimantan Tengah dan Kalimantan Timur mengalami perkembangan positif dan signifikan (sig < 0,05) dari tahun 2007 ke 2008, 2010, dan 2011, dimana untuk Kalimantan Tengah masing-masing ditunjukkan oleh nilai PC 0,635 dengan sig 0,011, nilai PC 0,602 dengan sig 0,018, dan nilai PC 0,533 dengan sig 0,041, dan untuk Kalimantan Timur masing-masing ditunjukkan oleh nilai PC 0,603 dengan sig 0,017, nilai PC 0,611 dengan sig 0,016, dan nilai PC 0,701 dengan sig 0,004. Hasil pemetaan markers radar menunjukkan peta opini LKPD di Kalimantan Barat berubah dari bentuk zig-zag sempit pada tahun 2007 - 2009 menjadi melebar stabil pada tahun 2011 (13 dari 15 entitas yang berada pada lingkaran ketiga peta), sedangkan peta opini LKPD di Kalimantan Tengah dan Kalimantan Timur tetap zig-zag hingga tahun 2011.

Dari 5.058 kasus rekomendasi hasil pemeriksaan BPK atas LKPD periode 2008 2012 di Kalimantan Barat, telah ditindaklanjuti dengan status sesuai rekomendasi 3.007 kasus (59,45\%) dengan nilai Rp 68,336 milyar (29,29\%), status dalam proses 1.546 kasus (30,57\%) dengan nilai Rp153,400 milyar (65,74\%), dan status belum ditindaklanjuti 506 kasus (10,00\%) dengan nilai Rp11,382 milyar (4,88\%). Di Kalimantan Tengah, dari total 6.152 rekomendasi BPK ditindaklanjuti dengan status sesuai rekomendasi 3.800 kasus (61,77\%) dengan nilai Rp126,569 milyar (34,65\%), status dalam proses 1.469 kasus (23,88\%) dengan nilai Rp149,284 milyar (40,87\%), status belum ditindaklanjuti 877 kasus (14,26\%) dengan nilai Rp 89,110 milyar (24,40\%), dan status tidak dapat ditindaklanjuti 6 kasus (0,1\%) dengan nilai Rp 300 juta (0,08\%). Di Kalimantan Timur, dari 4.249 
rekomendasi BPK ditindaklanjuti dengan status sesuai rekomendasi 2.350 kasus (55,31\%) dengan nilai Rp202,01 milyar dan USD1,262.72 ribu, status dalam proses 1.494 kasus (35,16\%) dengan nilai Rp 833,11 milyar (76,79\%) dan USD9,117.59 ribu, status belum ditindaklanjuti 402 kasus (9,46\%) dengan nilai Rp 49,58 milyar (4,57\%), dan status tidak dapat ditindaklanjuti 3 kasus (0,07 \%) dengan nilai Rp 0,15 milyar (0,02\%).

Saran. Mengacu kepada kesimpulan di atas, maka disarankan: (1) Perlu dilakukan pembinaan regular misalnya 6 enam bulan sekali kepada tim pengelola keuangan dan tim penyusun LPKD di setiap entitas pemerintah daerah.; (2) Untuk rekomendasi BPK yang belum ditindaklanjuti, perlu diprioritaskan pada kasus-kasus yang nilainya besar, sehingga jumlah kerugian negara yang berhasil diselamatkan meningkat signifikan.

\section{DAFTAR RUJUKAN}

Arens, A. A dan R.J. Elder, dan M.S. Beasley. (2003) Auditing dan Pelayanan Verifikasi: Pendekatan Terpadu, Edisi Kesembilan. PT. Indeks. Jakarta.

Badan Pemeriksaan Keuangan (BPK) (2013) Rencana Strategis. Badan Pemeriksaan Keuangan (BPK). http://www.bpk.go.id/page/rencana-strategis (download 16 Juni 2014)

Badan Pemeriksaan Keuangan (BPK) (2012a) Hasil Pemeriksaan atas LKPP Tahun 2011 Wajar Dengan Pengecualian. Siaran Pers. Biro Humas dan Luar Negeri. Jakarta.

Badan Pemeriksaan Keuangan (BPK) (2009) Tindak Lanjut Hasil Pemeriksaan BPK RI Semester I Tahun 2008. BPK Perwakilan Nusa Tenggara Timur. Kupang.

Badan Pemeriksaan Keuangan (BPK) (2007a) Juknis Pemeriksaan atas Laporan Keuangan Pemerintah Daerah (LKPD) Jakarta

Badan Pemeriksaan Keuangan (BPK) (2007b) Standar Pemeriksaan Keuangan Negara (SPKN). Jakarta

Badan Pengawasan Keuangan dan Pembangunan (BPKP) (2010) Akuntabilitas Pelaporan Keuangan. http://www.bpkp.go.id/konten/419/Akuntabilitas-Pelaporan-Keuangan. bpkp.

Madril, O. (2010) Ombudsman dan Pengawasan Terhadap Aparatur Negara Pasca Reformasi. Jurnal Inovasi (ISSN 2085-871X), Vol. 16 (22) hal 28 - 35

Mardiasmo. (2006). Perwujudan Transparansi dan Akuntabilitas Publik Melalui Akuntansi Sektor Publik: Suatu Sarana Good Governance. Jurnal Akuntansi Pemerintah Vol. 2 (1) hal 17

Milal, A. Z. (2013) Makna Opini Audit Wtp Bagi Kementerian/Lembaga (Studi Kasus Pada Kementerian Sosial). Universitas Brawijaya. Malang.

Mulyadi. (2002) Auditing Buku 1. Salemba Empat. Jakarta.

Pemerintah Daerah Kabupaten Magelang. (2011) Penyiapan Laporan Keungan Daerah. http://sipkd.magelangkab.go.id/materi/27122011/ (download 20 Maret 2014)

Pemerintah Daerah Provinsi Kalimantan Barat. (2013) Laporan Akuntabilitas Pemerintah Daerah di Provinsi Kalimantan Barat. Pontianak.

Pemerintah Daerah Provinsi Kalimantan Tengah. (2013) Penyusunan Draf Pelaporan Keuangan Semester I. Palangkaraya.

Pemerintah Daerah Provinsi Kalimantan Timur. (2011) Laporan Keuangan Pemerintah Daerah. Samarinda 
Peraturan Menteri Dalam Negeri Nomor 13 Tahun 2006 Tentang Pedoman Pengelolaan Keuangan Daerah

Peraturan Pemerintah No. 24 Tahun 2005 tentang Standar Akuntansi Pemerintahan

Rahmanti, V.N. dan A. Prastiwi. (2011) Analisis Faktor-Faktor Yang Menyebabkan Laporan Keuangan Pemerintah Daerah Beropini Disclaimer. Jurnal Akuntansi Multiparadigma, Vol 2 (2) hal 14

Sarwono, J., (2006) Analisis Data Penelitian Menggunakan SPSS. Penerbit ANDI. Yogyakarta.

Siregar, S.R. (2012) Faktor-Faktor Yang Mempengaruhi Pertimbangan Opini Auditor Atas Laporan Keuangan Pemerintah Daerah Istimewa Yogyakarta. Accounting Analysis Journal. Semarang. Universitas Negeri Semarang

Suroso, G.T. (2010) Reformasi Pengelolaan Keuangan Negara. Jurnal Keuangan dan Pembangunan. Jurnal Ilmiah dan Umum Berskala Nasional ISSN 2086-7263

Suwanda, D. (2013) Strategi Mendapatkan Opini WTP - Laporan Keuangan PEMDA. PPM Jakarta. Jakarta.

Undang-Undang Republik Indonesia Nomor 15 Tahun 2006 Tentang Badan Pemeriksa Keuangan.

Undang-Undang Republik Indonesia Nomor 15 Tahun 2004 Tentang Pemeriksaan Pengelolaan dan Tanggungjawab Keuangan Negara.

Undang-undang Nomor 33 Tahun 2004 tentang Perimbangan Keuangan Antara Pemerintah Pusat dan Pemerintah Daerah. 